\title{
DA RESPONSABILIDADE DO COMODATÁRIO PELO CASO FORTUITO OU DE FORÇA MAIOR - ACERCA DO PRINCÍPIO DO SACRIFÍCIO DA COISA PRÓPRIA*
}

\author{
THE LIABILITY OF THE BORROWER IN CASE OF ACT OF GOD OR IN FORCE MAJEURE: ABOUT \\ THE "PRINCIPLE OF THE SACRIFICE OF THE PROPER THING"
}

Rodrigo de Lima Vaz Sampaio**

\begin{abstract}
Resumo:
O devedor, em geral, exime-se do caso fortuito e da força maior pela regra "res perit domino". Entretanto, em certas circunstâncias, ele passa a responder por estes eventos. Neste contexto, no contrato de comodato existe um antigo dispositivo, atualmente previsto no art. $583 \mathrm{CC} / 2002$, segundo o qual o comodatário responde por exceção a esta regra, em uma hipótese que se passou a denominar do princípio do sacrifício da coisa própria. O presente artigo visa desenvolver tanto o fundamento quanto a pertinência desta hipótese frente ao parâmetro geral de responsabilidade do comodatário e as demais hipóteses pelas quais o comodatário responde agravadamente, vale dizer, justamente pelo caso fortuito ou de força maior.

Palavras-Chave: Responsabilidade civil. Caso fortuito ou de força maior. Responsabilidade agravada subjetiva e objetiva. Comodatário. princípio do sacrifício da coisa própria.
\end{abstract}

\begin{abstract}
:
The debtor, in general, does not exempt itself from the obligation in case of act of God or force majeure due to the "res perit domino" rule. However, in some cases, he is liable for these events. In this context, there is an old provision in the lending contract rules, with provision in the article 583 of the Brazilian Civil Code of 2002, by which the borrower is liable in the case of the principle of the sacrifice of the proper thing. The present article aims to develop not only its foundings as well as the convenience of this rule in terms of general parameters of liability of the debtor and other hypothesis which debtor's liability is aggravated in case of act of God or force majeure.
\end{abstract}

Keywords: Tort law. Act of God or force majeure. Subjective or strict aggravated liability. Borrower. Principle of the sacrifice of the proper thing.

\footnotetext{
Este artigo científico representa uma síntese do relatório final entregue ao CNPq (Conselho Nacional de Desenvolvimento Científico e Tecnológico), em cumprimento dos prazos fixados pelo PIBIC (Programa Institucional de Bolsas de Iniciação Científica). O trabalho foi desenvolvido sob a orientação do Professor Eduardo Cesar Silveira Vita Marchi, titular de Direito Romano da Faculdade de Direito da Universidade de São Paulo.

** Aluno do Curso de Graduação da Faculdade de Direito da Universidade de São Paulo.
} 
1. Introdução ${ }^{1}$

O comodato representa, dentro do âmbito jurídico, um papel especial, enquanto pode ser considerado uma das fontes de equilíbrio entre a cortesia e o direito, vale dizer, um momento diacrônico no qual o gesto de emprestar uma coisa para uso

\footnotetext{
Sobre o comodato no direito moderno e contemporâneo, entre os doutrinadores italianos, a maior monografia é de CARRESI, Franco. Il comodato - Il mutuo. In: VASSALLI, Filippo (Org.). Trattato di Diritto Civile Italiano. Torino: UTET, 1950. v. 8, t. 2, p. 5-13, reprisada, em grandes linhas, em Comodato (diritto civile). Novissimo Digesto Italiano, Torino, 1959. v. 3, p. 692-696. Ainda, em italiano, cf. as conhecidas obras de BRUNORI, Ernesto. Dei contratti specialli - comodato. In: FINZE, Enrico; D’AMELIO, Mariano (Orgs.). Commentario al Codice Civile. Firenze: Barbèra, 1949. v. 2, p. 1-507; BORSARI, Luigi. Commentario del Codice Civile Italiano. Torino: UTET, 1881. v. 4, t. 2, p. 5-936 (= §3914-4454); FRAGALI, Michele. Del comodato. In: SCIALOJA, Antonio; BRANCA, Giuseppe (Orgs.). Commentario del Codice Civile: Delle obligazioni. Bologna: Nicola Zanichelli, 1953. v. 4, t. 1, p. I-57, bem como as excelentes monografias e verbetes de LA FARINA, Cesare. Comodato. Enciclopedia Forense, Milano, v. 2, 1958. p. 308-313; PERRIS, Corrado. Comodato (contratto di). Nuovo Digesto Italiano, Torino, v. 16, 1938. p. 403-408; GIANTURCO, Emanuele. Contratti Speciali-Donazioni-Enfiteusi-Superficie-Mutuo-Comodato-Deposito-Sequestro. Napoli: Luigi Pierro, 1904. p. 7-303; BARBIERI, Ezio Maria; NAPOLETANO; Vicenzo; NOVITÀ, Mario. I contratti reali: mutuo - deposito - comodato - pegno - contratto estimatori. 2. ed. Torino: UTET, 1979, p. 3-579; MIRABELLI, Giuseppe. Il comodato - Il mutuo - La constituzione di rendita - Il deposito e il sequestro - Il pegno - Il contratto vitalizio - L'anticresi - La fideiussione - Il giuoco e la scommessa - La transazione. In: FIORI, Pasquale; BRUGI, Biagio (Orgs.). Il diritto civile italiano: Dei contratti speciali. Torino: UTET, 1924. v. 12, p. 3-748; TAMBURRINO, Giuseppe. Comodato (diritto civile). Enciclopedia del Diritto, Milano, v. 7, 1960, p. 994-1006; FORCHIELLI, Paolo. I contratti reali. Milano: Giuffrè, 1952. p. 1-177; SANTARELLI, Umberto. Comodato nel diritto medievale e moderno. Digesto delle Discipline Privatistiche: Sezione Civile, Torino, v. 3, p. 34-37, 1998.

Na literatura francesa, conferir as obras de BAUDRY-LACANTINERIE, Gabriel; WAHL, Albert. Traité théorique et pratique de droit civil: de la société, du prêt, du depôt. 2. ed. Paris: Des lois et des arrêts, 1900. p. 1-660 (= n. 1-1318); POTHIER, Robert-Joseph. Traités du prêt a usage et du precaire. In: Euvre de Pothier. 3. ed. Paris: Marchal et Billard, 1890. v. 5, p. 1-38 (=n. 1-97); TROPLONG, Raymond-Théodore. Le droit civil expliqué: du prêt. Paris: Charles Hingraus, 1845. t. 14, p. I-447 (= préface, n. 1-500). Como também LAURENT, François. Principes de Droit Civil Français. 3. ed. Bruxelles: B.C., 1878. t. 26, p. 5-554 (= n. 1-530) e PLANIOL, Marcel [et al.]. Traité pratique de droit civil français: Contrats civils. Paris: Générale de Droit, 1932, t. 11, p. 1-966 (= § 763-1605).

Quanto aos autores alemães, desca-se o trabalho de ENNECCCERUS, Ludwig; KIPP, Theodor; WOLFF, Martin. Lehrbuch des Bürgerlichen Rechts: Recht der Schuldverhältnisse. 28. ed. Marburg: G. Braun, 1928. v. 1, t. 2, p. 1-734 (= § 225-470), bem como a revisão desta executada por Heinrich. Lehmann, e a obra de KOBER, Karl; STAUDINGER, Julius Ritter. Leihe. In: Kommentar zum Bürgerlichen Gesetzbuch und dem Einführungsgesetz - Recht der Schuldverhältnisse. München: Schweitzer, 1929. v. 2, t. 2, p. 636-650 (=§598-606).

Por fim, quanto ao tratamento no direito romano, indica-se a obra de PASTORI, Franco. Il comodato nel diritto romano: Con contributi allo studio della responsabilità contrattuale. Milano: Cisalpino, 1954. p. XXII502, mesmo autor de Comodato (diritto romano). Novissimo Digesto Italiano, Torino, v. 3, 1959. p. 688692. Como também a de LUZZATTO, Giuseppe Ignazio. Caso fortuito e forza maggiore come limite alla responsabilità contrattuale - La responsabilità per custodia. Milano: Giuffrè, 1938. v. 1, p. 1-265, autor do verbete Custodia (diritto romano). Novissimo Digesto Italiano, Torino, v. 5, 1960. p. 92-94, e o trabalho de FERRINI, Contardo. Storia e teoria del contratto di commodato in Roma. In: Opere di Contardo Ferrini - Studi vari di diritto romano e moderno - Sulle Obligazioni, sul Negozio Giuridico, sulle Presunzioni. Milano: Ulrico Hoepli, 1929, v. 3. p. 81-203.
} 
gratuito é transformado em um negócio juridicamente relevante e produtor de precisos efeitos jurídicos obrigatórios. ${ }^{2}$

A importância vital deste contrato vem a se consolidar, sem qualquer dúvida, no que Agostinho Alvim denomina - muito espirituosamente - de "movimento do vaivém" da responsabilidade civil para designar à intercalação de um período em que vigorava a concepção objetiva e outro, baseado na idéia da culpa, a concepção subjetiva. ${ }^{3}$

Dentro deste movimento da responsabilidade civil, visa-se desenvolver o denominado princípio do sacrificio da coisa própria, previsto desde os primórdios do Direito, e que se tem repetido nas principais legislações do mundo, desejando-se entender seja sua existência, seja seu embasamento jurídico, a fim de que se compreenda adequadamente sua reiterada presença, não-obstante sua relativa escassez de aprofundada análise doutrinária.

Assim, em um primeiro momento, deve-se dedicar um exame pormenorizado às hipóteses de responsabilidade agravada no contrato de comodato, como exceção - subjetiva ou objetiva - ao princípio "res perit domino", pelo dano provocado à coisa emprestada por um caso fortuito, ou mesmo por uma força maior, dando margem, portanto, a criação de uma "responsabilidade agravada" do comodatário. ${ }^{4}$

Por fim, chega-se à parte fundamental que, em confronto com as demais hipóteses já analisadas, problematiza o princípio do sacrificio da coisa própria em seus principais aspectos.

2 Cf. SANTARELLI, Umberto. op. cit., p. 34-37. Ao se referir ao "fato" ou "momento diacrônico", este último autor entende que o comodato é o contrato por meio do qual se provoca a transformação de um simples gesto fático de cortesia em negócio jurídico relevante, ou, em outro sentido, refere-se ao caráter normativo conferido por um "costume imbuido de ética social", onde a força desta ética social assinalaria um sistema obrigatório, já constituído no momento em que um simples ato de liberalidade assume a conotação de um "negotium invicem gestum", e o rigor de uma "suscepta obligatio". V. também outros autores, como FORCHIELLI, Paolo. op. cit., p. 5, que se referem ao contrato de comodato como detentor de uma tripla realidade-jurídica, social e econômica - que, por si, já mereceria uma análise pormenorizada de sua estrutura.

3 ALVIM, Agostinho. Da inexecução das obrigações e suas conseqüências. 5. ed. São Paulo: Saraiva, 1980. p. 243 (= ns. 169-170). Embora a teoria clássica - que de "clássica" neste sentido apenas teria o nome - entenda que a culpa é um elemento indispensável da responsabilidade, esta concepção é muito mais recente frente à idéia da custódia romana, que, segundo este último autor, estava em sua máxima expressão nos "tempos primitivos" do direito. Esta antiga idéia objetiva de responsabilidade teria hoje retomado seu antigo brilho, ofuscando a exigência da culpa como requisito caracterizador das finalidades intrínsecas à responsabilidade civil.

4 A expressão "responsabilidade agravada" será utilizada neste artigo com o sentido de "responsabilidade pelo caso fortuito elou pela força maior". Este uso é justificado pela utilização na doutrina, seja nacional, seja internacional, da expressão com este sentido preciso. Assim, entre outros, BRUNORI, Ernesto. op. cit, p. 26: "C'è chi há visto nella stima un automatico aggravamento di responsabilită", BEVILAQUA, Clóvis. Código Civil dos Estados Unidos do Brasil. São Paulo: Francisco Alves, 1917, v. 4, p. 437: "Este dispositivo [art. 1253 CC/1916] accentua o grau de zelo a que o commodatario é obrigado na conservação do objecto emprestado". FONSECA, Arnoldo Medeiros da. Caso fortuito e teoria da imprevisão. 2. ed. Rio de Janeiro: Imprensa Nacional, 1943. p. 173, utiliza exatamente a expressão "responsabilidade agravada". 
2. Os parâmetros gerais da responsabilidade do comodatário no tempo

A evolução da história do Direito Romano expõe a existência de três fases distintas quanto ao aprimoramento da responsabilidade do comodatário, sendo que seus fundamentos aproximam-se da responsabilidade que se denomina "responsabilità obiettiva per custodia", a partir da qual o comodatário seria automaticamente responsável uma vez que determinados eventos ocorressem. ${ }^{5}$

Durante o período clássico, na responsabilidade do comodatário predominava o aspecto objetivo, que não apenas reforça a premissa histórica do estudo deste contrato, como, principalmente, explica a concepção do comodato como um contrato real ofuscando-se todos os demais argumentos neste sentido.

Com os compiladores, a responsabilidade do comodatário chegaria a uma segunda fase caracterizada pelo estabelecimento do critério da diligentia ${ }^{7}$ através da qual seriam construídas graduações de sua responsabilidade, tendo como referência a utilitas, o que determinaria a terceira e última fase da evolução que viria com a adoção do aspecto subjetivo da culpa. $^{8}$

Na Idade Média, o comodatário passou a ser visto como o único beneficiado no contrato de comodato, e, assim, tornou-se sempre responsável pelo caso fortuito, embora houvesse exceções, pelas quais o comodatário se exonerava da obrigação, baseadas em uma "aequitas naturalis". 9

Segundo o entendimento de Franco Carresi, ${ }^{10}$ a obrigação do comodatário de custodiar e conservar a coisa com a diligência de um bonus paterfamilias constitui, rigorosamente, um verdadeiro sinônimo para as obrigações do comodatário, ou seja, seria o ponto de partida para o desmembramento do feixe das obrigações do comodatário ou uma moldura que conteria todas as demais obrigações do comodatário, podendo, assim,

\footnotetext{
Cf. BRUNORI, Ernesto. op. cit., p. 22-23, para o qual, embora esta concepção não possua uma influência direta na disciplina do comodato no mundo contemporâneo, esta primeira fase é a que determina - aliás, é a única que determinaria, neste sentido - uma influência indireta na atualidade. Entretanto, desde já se alerta que as três fases da responsabilidade do comodatário não são estanques, como bem demonstra SERTORIO, Luigi. La "culpa in concreto" nel diritto romano e nel diritto odierno. Torino: Fratelli Bocca, 1914. p. 41-43, para o qual subsiste, mesmo no período pós-clássico, um substrato objetivo na responsabilidade do comodatário.

6 Sobre a realidade v. a monografia de FORCHIELLI, Paolo. op. cit., p. 2-5, 9, 109-110, 114-121.

7 BRUNORI, Ernesto. op. cit., p. 22-23.

8 Id. Ibid.

9 A exceção que bem representa esta "aequitas naturalis" era o caso do animal que viesse a ser assassinado ou que de qualquer forma morresse, sendo que o comodatário não seria responsável se não fosse ele fonte de dano ou que não tivesse aferido com este evento qualquer vantagem. Esta regra própria do período medieval terá uma influência significativa na evolução e caracterização do princípio do sacrifício da coisa própria. V., em especial, os itens 4.2 e 4.3, para desenvolvimento do contrato de comodato na Idade Média e da fattispecie em questão.

10 CARRESI, Franco. Il comodato - Il mutuo. cit., p. 59-61 (= § $38-39)$.
} 
ser considerada a norma principal, presente no art. $1.804, \S 1^{\circ}$ do CC italiano, em contraste a todas as demais obrigações, que seriam acessórias. ${ }^{11}$

Dentro deste contexto, a responsabilidade agravada pelo risco de perecimento simultâneo da coisa dada em comodato e de outra própria do comodatário deveria ser vista como obrigação pontual que delimita seus efeitos não por sua obrigação principal, mas por si só, ${ }^{12}$ tornando-se a única hipótese aceitável para o agravamento da responsabilidade do comodatário, já que prevista no art. $1.805, \S 1^{\circ}$ do CC italiano. Em outros termos, somente esta obrigação - que, desta maneira, detém o caráter de excepcional - escapa da moldura, do parâmetro unitário da obrigação de custodiar e conservar a coisa com a diligência de um bonus paterfamilias. ${ }^{13}$

Entretanto este critério concentrador da obrigação de custodiar e conservar a coisa emprestada, e excepcional frente princípio do sacrifício da coisa própria, é criticado por Giuseppe Tamburrino, ${ }^{14}$ alegando que se tratava de um critério doutrinário

11 Id. Ibid., p. 59-61 $(=\S 38-39)$. Assim, institui um caráter unitário, frente ao qual todas as obrigações do comodatário devem ser entendidas, compreendidas, analisadas e delimitadas.

12 Id. Ibid.

13 Id. Ibid. Esta cartografia especial da responsabilidade do comodatário demonstra que, enquanto o parâmetro aceito pela communis opinio para a obrigação de custodiar e conservar a coisa com a diligência de um bom pai de família é a culpa levis in abstracto, sofre-se um aumento no conteúdo desta diligência, embora o autor considere este aumento generalizado da diligência em parte ilógico, na hipótese de perecimento acima referida. Excetuando esta hipótese, todas as demais, enquadram-se na obrigação de custódia e conservação da coisa com a diligência de um bom pai de família. $\mathrm{O}$ comodatário, assim, apresenta duas obrigações: a de custodiar e conservar a coisa com a diligência de um bom pai de família, presente no art. $1.804, \S 1^{\circ}$ do CC italiano, e a hipótese de responsabilidade agravada pelo perecimento da coisa, prevista no art. $1.805, \S 1^{\circ}$ do CC italiano. O caráter concentrador da obrigação de conservar e custodiar a coisa emprestada, no Brasil, foi sustentado por FRANÇA, Rubens Limongi. Contrato de empréstimo. Enciclopédia Saraiva do Direito, São Paulo, v. 19, 1977, p. 320-324. Esta cartografia particular das obrigações do comodatário, realizada por Franco Carres, viria a se alterar, com o passar do tempo na obra CARRESI, Franco. Comodato (diritto civile), p. 692-696. Segundo esta versão, o direito do comodatário configura-se em um aspecto positivo - o direito de uso da coisa de acordo com o estabelecido no contrato -, mas, com igual importância, em um negativo - a obrigação de "custódia e conservação da coisa com a diligência de um bom pai de família", que não seria própria e tecnicamente uma obrigação, não detendo mais um caráter centralizador, mas permearia e conferia vida a todas as demais obrigações do comodatário. É como se este limite negativo estivesse presente em todas as obrigações do comodatário, sendo o caráter comum a todos estes, mas sem a possibilidade de ter vida autônoma. Na realidade, duas apenas seriam as obrigações do comodatário: aquela de suportar as despesas necessárias e urgentes com a coisa emprestada e a obrigação de a salvar do perecimento sacrificando uma própria ou, no caso de apenas poder salvar uma coisa entre as duas, de preferir salvar a emprestada ao invés da própria, previstas, respectivamente nos arts. 1.808 e $1.805, \S 1^{\circ}$ do CC italiano. Na prática, somente há uma diferença vital. Sem gozar de autonomia, a existência da obrigação de custodiar e conservar a coisa emprestada depende da configuração das demais obrigações do comodatário, isto é, se uma de suas obrigações não se configuram não há a incidência da custódia e conservação da coisa com a diligência de um bom pai de família. Neste sentido conferir também BARBIERI, Ezio Maria; NAPOLETANO; Vicenzo; NOVITÀ, Mario. op. cit., 387-389.

14 TAMBURRINO, Giuseppe. op. cit., p. 994-1.006. Trata-se da obrigação de vigiar a coisa emprestada e agir de maneira que sua integridade e perfeita solidez sejam mantidas para que a coisa não sofra qualquer alteração em sua substância e seja devolvida no mesmo estado em que foi recebida. O art. 1804 , $\S 1^{\circ}$ do CC italiano é, com absoluta certeza, uma disposição cogente, que, além de não poder ser afastada pelas 
inadequado, uma vez que o que deveria prevalecer seria um critério legal, porque é deste que derivaria diretamente a relação de obrigações do comodatário.

A discussão acerca do critério segundo o qual o comodatário responde pela obrigação de conservar e custodiar a coisa emprestada remonta, no século XIX e XX, ao famoso fragmento de Gai. 9 ad ed.provinc., D. 13, 6, 18 pr.

Sobre este, Robert-Joseph Pothier ${ }^{15}$ sustentou não bastar o cuidado de um homem médio, mas sim de todo o cuidado possível, aquele que a pessoa mais diligente e escrupulosa teria. ${ }^{16}$

Entretanto, a posição majoritária ainda permanece com João Manuel De Carvalho Santos, ${ }^{17}$ pelo qual a conservação impõe ao comodatário certa dose de vigilância, ou seja, a atenção normal de um prudente administrador - "culpa levis in abstracto" - capaz de ter o cuidado que um bom pai de família tem com suas próprias coisas, podendo este provar que a coisa pereceu sem que tenha concorrido com sua culpa para isentar de responsabilidade, salvo determinadas exceções. ${ }^{18}$

partes, limita e delimita o parâmetro de aferição da responsabilidade do comodatário à culpa levis, sendo qualquer discussão acerca desta arcaica e superada pela lei. Esta posição viria impedir qualquer gradação da responsabilidade do comodatário. O direito brasileiro, embora a primeira vista tenha optado pela "culpa levis in concreto", aliás como sustenta a minoria da doutrina, como RODRIGUES, Silvio. Contrato de comodato. Enciclopédia Saraiva do Direito, São Paulo, v. 19, 1977, p. 237-241, tem admitido, majoritariamente, como, entre outros, BEVILAQUA, Clóvis. op. cit., p. 435-437, a "culpa levis in abstracto". O comodatário deve zelar pela coisa emprestada não como se fosse sua, mas, mais precisamente, deve ter um cuidado extremo para com a coisa emprestada, pois se tenta evitar que qualquer coisa alheia se submeta aos desleixos de perdulários e esbanjadores. De forma semelhante, GONÇALVES, Luiz da Cunha. Tratado de direito civil: em comentário ao código civil português. 2. ed. São Paulo: Max Limonad, 1956. v. 8, t. 1, p. 309 (=§ 1148), diz que o art. 1.514 do CC português, com a mesma redação inadequada do Código Civil brasileiro de 2002, enuncia o cuidado que o comodatário deve ter com a coisa emprestada "como se fora sua", mas, na realidade, o legislador acaba por presumir que o comodatário, como qualquer outra pessoa, agirá de uma forma mais zelosa frente às coisas que lhe pertencem do que em relação àquelas emprestadas. Assim, esta disposição não deve ser assim compreendida, em primeiro lugar porque existem muitas pessoas desleixadas com as próprias coisas, o que colocaria em autêntico risco as emprestadas. E, em segundo lugar, porque, seguindo as melhores legislações estrangeiras vigentes, como o art. 1.880 do CC francês e o art. 1.745 CC espanhol - este último prevendo a "culpa levissima" -, ou já revogadas, como as Orden. Filip. (Ordenações Filipinas) 4, 53, 2, não se adota a "culpa levis in concreto", mas, pelo contrário, prefere-se a "culpa levis in abstracto".

15 POTHIER, Robert-Joseph. Traités du prêt a usage et du precaire. In: Euvre de Pothier. 3. ed. Paris: Marchal et Billard, 1890, v. 5, p. $19(=\S 48)$.

16 Idéia esta que persiste ainda no direito brasileiro com DIAS, José de Aguiar. Comodato. Repertório Enciclopédico do Direito Brasileiro, Rio de Janeiro, v. 10, 1947, p. 24-26.

17 SANTOS, João Manuel de Carvalho. Código Civil Brasileiro Interpretado. 8. ed. Rio de Janeiro: Freitas Bastos, 1964. v. 17, p. 410-411. Posição equivalente a de CARRESI, Franco. Il comodato - Il mutuo. cit., p. 59-61. Exigi-se a vigilância padrão do homem que cuida diligentemente de seus interesses para que o comodatário não deva qualquer indenização ao comodante ou responda pela perda da coisa, e, até mais que isso, pois em algumas hipóteses exigi-se zelo maior com o objeto do empréstimo do que com as próprias coisas do comodatário.

18 SANTOS, João Manuel de Carvalho. op. cit., p. 59-61. 
A assunção deste critério para determinar a responsabilidade do comodatário frente à obrigação de custodiar e conservar a coisa emprestada teria levado o legislador a abandonar tanto a tripla teoria da gradação da culpa, já adotada no Direito Romano, quanto ao princípio da maior diligência possível, até pela maior facilidade de se julgar o comportamento do comodatário em confronto com a diligência de um bom pai de família. ${ }^{19}$

Assim, atualmente, o comodatário responde de maneira unitária, vigorando a concepção da uniformidade da diligência do bonus paterfamilias como parâmetro único na comensuração da responsabilidade do comodatário. ${ }^{20}$

Esta concepção permite descartar as hipóteses, chamadas, em analogia com a terminologia utilizada por Arnoldo Medeiros da Fonseca, ${ }^{21}$ de "hipóteses aparentes de responsabilidade agravada", 22 em que o comodatário não responde pelo "caso", uma vez

19 PERRIS, Corrado. op. cit., p. 403-408. Em outros termos, a diligência que o comodatário deve empregar no adimplemento da obrigação é sempre aquela estabelecida como regra geral no art. 1.224 do CC italiano de 1865 revog, de onde se fala dos efeitos das obrigações, e que se aplica ao comodatário por previsão expressa do art. 1.808 do CC italiano de 1865 revog., mesmo que a utilidade sobre a constituição do comodato varie conforme se beneficie uma parte ou a outra. Esta obrigação do comodatário de vigiar a coisa com a diligencia de um bom pai de família não sofreria, no posicionamento deste último, qualquer exceção ou limitação. Logo, também é culpa do comodatário mesmo se deste exige um empenho, um comportamento, maior que suas próprias forças, se não pode adimplir a obrigação contratada. No mesmo sentido FERRARIO, G. A. Comodato. Enciclopedia Giuridica Italiana, Milano, v. 3, 1930, p. 385-405. De forma semelhante, BRUNORI, Ernesto. op. cit., p. 22-23, na medida que nega a importação da gradação da culpa no Direito moderno.

20 BRUNORI, Ernesto. op. cit., p. 22-23 .

21 FONSECA, Arnoldo Medeiros da. op. cit., p. 174-180. A partir desta distinção será possível diferenciar as hipóteses "aparentes" de responsabilidade agravada, daquelas em que o comodatário efetivamente responde pelo "caso", seja subjetiva - o que também as coloca no parâmetro da "culpa levis in abstracto" -, seja objetivamente - que foge de qualquer parâmetro de culpa.

22 Assim, não se pode confundir as hipóteses de responsabilidade agravada do comodatário com aquelas denominadas hipóteses aparentes de responsabilidade do comodatário, isto é, aquelas em que ou o caso fortuito e a força maior não se configuram, ou estão inseridas dentro do parâmetro genérico da "culpa levis abstracta valorizada".

A primeira destas hipóteses aparentes é aquela, para CARRESI, Franco. Il comodato - Il mutuo, cit., p. 62 $(=\S 40)$, que se refere a um caso que não seja propriamente uma força maior. Este evento seria aquele em que o caso fortuito ou a força maior não chegam a se concretizar por uma ação específica, e seriam, por isso denominado de "quase força maior", por TAMBURRINO, Giuseppe. op. cit., p. 994-1006, embora mais tecnicamente se deva falar de "quase caso fortuito". A ação específica que impede a caracterização do caso fortuito seria a efetuação de uma despesa extraordinária realizada pelo comodatário, que teve que ser a antecipada por completo e imediatamente para que o perecimento da coisa emprestada não ocorresse, sob pena de ser por este responsabilizado. E, por se tratar de uma despesa extraordinária, o comodatário terá o direito ao reembolso, como sustenta Franco Carresi, o qual percebe que toda esta questão está no fato de não existir qualquer contradição entre o direito de reembolso do comodatário em casos como este e a regra res perit domino, ou com a própria essência do contrato, baseado na relação de cortesia entre as partes e na realização de um favor. A despesa extraordinária vem a constituir uma verdadeira válvula de escape, nos termos de Giuseppe Tamburrino, para que o comodatário não responda pelo perecimento do bem, imbuído de um verdadeiro caráter preventivo, vale dizer, é a última fronteira, o limite entre a obrigação de custodiar e conservar a coisa com a diligência de um bom pai de família e uma hipótese autêntica de responsabilidade agravada. Não há, assim, dúvidas que nestas circunstâncias o "quase caso fortuito" estaria circunscrito na obrigação de custodiar e conservar a coisa com a diligência de um bom pai de família e não, em uma segunda 
obrigação do comodatário, prevista no art. $1.805, \S 1^{\circ}$ do CC italiano, referente ao princípio do sacrificio da coisa própria. Mas esta hipótese, para FRAGALI, Michele. op. cit., p. 213, somente se justifica frente a previsão de um sistema de re-embolso das despesas extraordinárias.

A segunda hipótese aparente de responsabilidade agravada, em complementação da primeira é o nãopagamento das despesas ordinárias, uma vez que, no entendimento de CARRESI, Franco. Il comodato - Il mutuo, cit., p. $62(=\S 40)$, p. 61-63 (= $\S 40)$ se a efetuação de uma despesa extraordinária impede a danificação da coisa emprestada, também à obrigação de efetuar uma despesa ordinária decorre da grande e concentradora obrigação de custodiar e conservar a coisa com a diligência de um bom pai de família, vale dizer, tanto as despesas ordinárias como extraordinárias decorrem da obrigação de custodiar e conservar a coisa com a diligência de um bom pai de família, porém, apenas para as extraordinárias, o comodatário tem o direito de reembolso, uma vez que este representa uma limitação das obrigações e direitos do comodante, apenas se preservando os direitos inerentes a propriedade. Porém, se, de fato, a obrigação de reembolsar o comodatário derive apenas das despesas extraordinárias, isto não significa que todas as despesas com a coisa corram diretamente por conta do comodatário. O comodante, frente às despesas que o comodatário não é obrigado a cobrir, deve suportá-las, seja por não apresentarem os dois requisitos das extraordinárias - a necessidade e a urgência -, seja porque colocaria o comodatário em uma situação agravada economicamente. Portanto, o parâmetro de responsabilidade continua a ser a "culpa levis in abstracto valorada", além do que o agravamento da responsabilidade do comodatário não se configura, porque o que se suporta são as "spese di conservazione" para FRAGALI, Michele. op. cit., p. 204-206, vale dizer, não-somente aquelas referentes a uma obra de reparação, como no caso do locador, mas inclusive aquelas que não almejam tal efeito. Neste sentido, BEVILAQUA, Clóvis. op. cit., p. 437-438, sustenta que já em Gai. 9 ad ed. provinc., D. 13, 6, 18, 2, a obrigação do comodatário sobre as despesas foi de alguma forma regulada e restringida a certas espécies, o que significaria que durante muito tempo o comodatário poderia cobrar do comodante as despesas de maior valor, chamadas de majorae impensae, mas não as módicas.

A última hipótese aparente se refere ao princípio da deterioração ou perecimento natural decorrente do uso. Para BORSARI, Luigi. op. cit., p. 108-109, 114 (= §§ 3964, 3967), por sua própria concepção, não é possível existir um empréstimo sem algum incômodo, pois além do empréstimo privar o comodante do uso de sua coisa por certo tempo, pode este mesmo uso por ele permitido ser causa da deterioração da coisa. O comodante ao emprestar a coisa não pode prever todos os acontecimentos possíveis que possam a vir danificar, mas é o comodatário a pessoa mais capacitada e adequada a conhecer tais vicissitudes. Quem se utiliza assim do empréstimo é capaz, de conhecer e reconhecer se não convém, em certas circunstâncias, diminuir o serviço atribuído à coisa, seja porque a estrada é muito cansativa e ruim, seja porque percebe que o cavalo não está habituado com o trabalho, seja porque se encontra cansado em baixo do moinho ou mesmo se não o necessitará para o trabalho. Assim, o comodatário não deve durante o uso violar a reserva legal de não colaborar com culpa ao dano. $\mathrm{O}$ objeto do comodato em si e a finalidade para o qual este foi conferido não configuram um trajeto de conduta para o comodatário, nem são suficientes para caracterizar sempre a hipótese de dano decorrente somente do uso, devendo as circunstâncias concretas serem consideradas por este para que este não coloque em risco a existência e a integridade da coisa.

O objeto dado em comodato e o uso o qual serve devem ser maximizados no caso concreto na medida do possível, vale dizer, sem que uma deterioração anormal, decorrente de um erro na quantificação do serviço, ou mesmo de circunstâncias supervenientes, ocorra. Desde o Direito Romano a solução adotada era contrária ao proprietário, o que levou os publicistas a pensarem de uma forma diversa, baseando-se na existência de uma condição tácita e implícita no contrato, pela qual o comodatário deveria ressarcir sempre o dano gerado ao comodante, pelo simples motivo de ter recebido um favor gratuito deste. A respeito desta regra, a racionalidade de POTHIER, Robert-Joseph. op. cit., p. 21-23 (= n. 55), superou uma antiga eleição que os autores realizavam, depositando seus votos ora em uma jurisprudência, ora em outra, formulando uma regra de autêntico e inquestionável valor prático. Trata-se da constatação de que se o uso for a causa produtora do dano sofrido pelo comodante, este deve ser ressarcido, mas não o será se o uso for apenas uma mera ocasião. Para BORSARI, Luigi. op. cit., p. 108-109, $114(=\S \S 3964,3967)$, apenas um defeito pode se apresentar na regra, justamente quando a causa do perecimento é conseqüência do uso. A regra da ocasião prevalece, vale dizer, se o uso tivesse como conseqüência direta a causa do perecimento, tornando-se o uso a causa, se o comodatário não concorrer com qualquer culpa, não deve indenizar. Mas, a afirmação ideal de que cada dano 
que este não se caracteriza, o que as coloca dentro deste parâmetro unitário da "culpa levis in abstracto".

O cuidado a ser tomado é sinalizado por Franco Carresi, para o qual o parâmtro da "culpa levis in abstracto" não deve ser alterado, mas deve ocorrer, nas obrigações que dentro dela se inserirem, uma valoração desta diligência, com maior ou menor rigor, para que se determine o quanto do desvio desta diligência que causará a imputação da responsabilidade para o comodatário. ${ }^{23}$

Desta forma a obrigação de custodiar e conservar a coisa com a diligência de um bom pai de família representa uma mescla das principais correntes que tentaram estabelecer seus parâmetros, sendo que o parâmetro é, o que se poderia denominar de "culpa levis in abstracto valorizada".

3. Outras hipóteses de responsabilidade agravada do comodatário

3.1. A mora e o uso diverso como hipóteses distintas de responsabilidade agravada

Dentre as hipóteses de inversão legal do risco, ${ }^{24}$ isto é, aquelas em que se excepciona verdadeiramente a regra "res perit domino", transferindo-se os riscos derivados do "caso", encontra-se a hipótese de uso diverso da coisa emprestada e a mora,

sentido pelo comodante deve ser reembolsado pelo comodatário e a regra "causa-ocasião" configuram a imaginação de uma condição implícita, que pode ou não subsistir, dependendo da veracidade desta afirmação em cada ordenamento jurídico. Configurada esta condição, a máxima não se aplica de forma implícita, mas apenas de modo expresso. O Direito italiano - bem como o brasileiro - exige menção expressa da máxima, não se concretizando de forma implícita, até porque a presença de uma cláusula desta no sistema valorizaria o comportamento egoísta, reforçando a máxima de que o empréstimo custa muito mais caro a quem o faz, do que a quem o recebe. Assim, o núcleo do princípio da deterioração ou do perecimento natural pelo uso da coisa está na prova a ser efetuada pelo comodatário de que a deterioração ou perecimento identificam-se ou provém do próprio uso da coisa. Trata-se de um princípio inquestionável e de absoluto critério de justiça e bom senso, de modo que é simples a prova de que o desfalecimento da coisa deriva dela própria ou do modo como foi acordado em usá-la. Por fim, para BRUNORI, Ernesto. op. cit., p. 24-28, a regra de Ulp. 28 ad. ed., D. 13, 6, 5, 3, demonstra a imprecisão do art. 1.807 do CC italiano., cópia do art. 1.812 do CC italiano de 1865, uma vez que o dispositivo apenas fala em deterioração, e não em perecimento e, para FRAGALI, Michele. op. cit., p. 211-213, a expressão "senza colpa del comodatario", deste mesmo dispositivo, é muito restrita, pois se percebe que existem eventos que podem ocorrer sem a culpa do comodatário, e que são à ele imputados, principalmente alguns eventos fortuitos.

23 CARRESI, Franco. Il comodato - Il mutuo, cit., p. 59-61 (= § 39). Um exemplo em que ocorre uma valoração com maior rigor ocorre quando o comodatário pede o empréstimo longamente ao comodante, e com menor rigor, quando o comodante insiste para que o contrato seja concluído.

24 Assim, BORSARI, Luigi. op. cit., p. 107-110 (= \$ 3.964), em um desabafo, diz que o princípio res perit domino é absoluto e incontestável, uma vez que permanece vigente e intocável em sua personificação no direito de propriedade e após o empréstimo e destruição da coisa por causa não imputável a comodatário. Porém, a aplicação deste princípio ao contrato de comodato torna-se uma tarefa árdua e que merece uma análise detida e esmiuçada. 
que devem ser tratadas como distintas, embora a uniformidade de tratamento se apresente na legislação. ${ }^{25}$

Esta previsão ocorre no art. $1.805, \S 2^{\circ}$ do $\mathrm{CC}$ italiano, ${ }^{26}$ o qual repete, na parte referente à mora, o texto do art. $1.221, \S 1^{\circ}$ do CC italiano, uma vez que a hipótese do uso diverso da coisa emprestada é específica e própria do comodato, e não das obrigações ou dos contratos em geral.

Entretanto a maior confluência entre os textos normativos, que repetem os arts. 1.809 e 1.298 do CC italiano, de 1865 , não se encontram na sua literalidade, mas na previsão de uma "praesumptio iuris tantum", 27 a partir da qual se afirma existir uma responsabilidade agravada subjetiva do comodatário em tais hipóteses, a qual pressupõe e se justifica na violação do contrato.

A "praesumptio iuris tantum" caracteriza a existência do nexo de causalidade entre a violação do contrato, por uso não previsto ou por estado de mora, e o perecimento da coisa, ${ }^{28}$ podendo ser afastada mediante a prova, feita pelo comodatário, que demonstre

25 Cf. FRAGALI, Michele. op. cit., p. 214.

26 FRAGALI, Michele. op. cit., p. 214. Similar em conteúdo quanto ao art. 582 CC/2002, o que demonstra que, embora previstas no mesmo dispositivo legal, o mais aconselhável é seu tratamento apartado, e quiçá uma sugestão de desmembramento do dispositivo em dois. Neste entendimento também se encontra LA FARINA, Cesare. op. cit., p. 308-313, que se refere ao atraso no cumprimento da obrigação como caso que se enquadra na moldura genérica do conceito de mora, enquanto o desvio para um uso diverso não caracteriza a mora, mas antes uma conduta intimamente reprovável do comodatário que viola a própria natureza do contrato. Quanto ao uso que o comodatário pode realizar v. BARBIERI, Ezio Maria; NAPOLETANO; Vicenzo; NOVITÀ, Mario. op. cit., p. 388-389. É certo que o comodatário somente pode se servir da coisa no limite do estabelecido expressamente. O comodatário não pode se servir da coisa emprestada para um uso diverso daquele determinado pelo contrato ou pela natureza da coisa, sob pena de imediata restituição da coisa emprestada ao comodante, além de responder pelo ressarcimento do dano. Assim, o comodatário deve custodiar e conservar a coisa com a diligência de um bom pai de família, e na falta desta responde pelos danos ocasionados, que irão se transferir aos herdeiros no caso de seu falecimento. O fato do comodatário usar a coisa para um fim diverso ou por um tempo mais longo que o previsto o imputará o dano ocasionado, mesmo se este derive de causa para o qual não concorreu, embora ainda possa provar que a coisa teria se perdido mesmo se não à usasse em desconformidade com a previsão ou a tivesse restituído à tempo. Entretanto, se admite que o dano também não seja ressarcível por parte do comodatário, se o proprietário da coisa emprestada poderia evitá-lo, utilizando de diligência ordinária. Assim, o comodatário assume, através da figura da custódia, a defesa da integralidade da coisa emprestada, mesmo que o dano decorra de fato alheio, ou seja, decorrente de um terceiro, embora não haja dúvida que seja mero detentor desta. Ainda, a respeito do uso que o comodatário pode realizar v., no direito brasileiro, RODRIGUES, Silvio. op. cit., p. 237-241, FRANÇA, Rubens Limongi. op. cit, p. 320-324 e DIAS, José de Aguiar. op. cit., p. 24-26.

27 FRAGALI, Michele. op. cit., p. 214. Também pela defesa da configuração de uma "praesumptio iuris tantum". PERLINGIERI, Pietro. Codice civile annotato con la dottrina e la giurisprudenza: delle obbligazioni. Napoli: Scientifiche Italiane, 1991, v. 4, t. 2, p. 1364.

28 V. FRAGALI, Michele. op. cit., p. 214. Sempre caracterizará uma responsabilidade por culpa ou dolo do comodatário, porque na ausência de prova em contrário, determina-se que a violação do comodatário foi causa do perecimento, não sendo, portanto, necessário que o comodante prove o nexo entre o inadimplemento e o evento fortuito. Trata-se da percepção suficiente para caracterizar a hipótese como de responsabilidade agravada subjetiva, reforçada pela criação de uma "praesumptio iuris tantum", ou seja, que contenha a possibilidade de afastar a responsabilidade por (contra-) prova da não culpa. 
o igual perecimento da coisa mesmo se o contrato não tivesse sido violado por qualquer das duas hipóteses. ${ }^{29}$

Além disso, para Cesare La Farina, ${ }^{30}$ a configuração destas hipóteses leva o comodatário a responder em ambas não-somente pelo valor da coisa, mas também pelo dano gerado, e Michel Fragali ${ }^{31}$ afirma que a responsabilidade agravada do comodatário é acima de tudo, nestas duas hipóteses, uma responsabilidade por culpa, ou mesmo o que se denominaria de uma responsabilidade indireta, já que o perecimento não foi desejado pelo comodatário, sendo um efeito da violação do contrato. ${ }^{32}$

Neste sentido, sustentando a idéia que o comodatário ao violar o contrato, deve responder por qualquer dano causado à coisa emprestada, Ernesto Brunori, ${ }^{33}$ classifica esta violação em duas ordens, sendo esta o primeiro requisito para caracterizar qualquer das duas hipóteses.

A primeira recairia sobre seu conteúdo - abusando da coisa -, enquanto que, pela segunda, a violação incidiria sobre sua duração - retendo a coisa por prazo além do determinado. ${ }^{34}$

${ }_{29}$ Cf. BRUNORI, Ernesto. op. cit., p. 24-25, sustenta que embora a prova não seja prevista expressamente pelo direito italiano, conclui-se que esta existe e é válida, seja direta ou indiretamente, pelo sistema, embora a sustentação errônea de que ela teria sido derrogada pelo Codice Civile italiano de 1942. Esta prova tem sido admitida em quase todas as legislações com exceção daquelas, como o art. 322 do Schweizerisches Zivilgesetzbuch, pelo qual não se deve admitir a exclusão da responsabilidade do comodatário quando em mora, embora utilize a coisa para o fim determinado, ou de emprego em uso diverso sob o argumento de que o prejuízo advindo por caso fortuito ou pela força maior teria se produzido mesmo se o comodatário não tivesse culposamente violado o contrato, conforme GONÇALVES, Luiz da Cunha. Tratado de direito civil - Em comentário ao Código Civil português. cit., p. 310-316 (= §1148).

30 LA FARINA, Cesare. op. cit., p. 308-313.

31 FRAGALI, Michele. op. cit., p. 214.

32 A mesma solução se encontra ao se aplicar a regra de RADOUANT, Jean. Du cas fortuit et de la force majeure. Paris: Rousseau, 1920, p. 181-183, pela qual quando a culpa é anterior, ela pode determinar diretamente o evento do "caso", e se posterior ao evento fortuito, pode aumentar seus efeitos.

33 BRUNORI, Ernesto. op. cit., p. 24-25.

34 KOBER, Karl; STAUDINGER, Julius Ritter. op. cit., p. 644-645 (= § 603) tratam da mora como a limitação temporal do uso. 
O dano ${ }^{35}$ ocasionado à coisa emprestada enquanto o comodatário encontravase em mora, segundo Luigi Borsari ${ }^{36}$ só ocorreu, pois o comodatário não realizou o seu dever, pois caso o tivesse, nenhum dano viria a acometer a coisa. ${ }^{37}$

Como bem enuncia Clóvis Bevilaqua ${ }^{38}$ a regra do comodatário moroso é a de qualquer outro devedor se obriga tanto pela deterioração, como pelo perecimento, ao se encontrar nesta condição.

Entretanto, para Gabriel Baudry-Lacantinerie e Albert Wahl, ${ }^{39}$ quando o art. 1.881 do CC francês descreve a conduta culposa do comodatário nestas hipóteses, impõese a necessidade de um segundo requisito.

Este seria o nexo de causalidade existente entre seu ato culposo e o "caso", 40 vale dizer, somente se a coisa perecer por um caso fortuito, para o qual não teria sido exposta sem a culpa prévia do comodatário, que contribui indiretamente para o evento, o comodatário é responsável, embora não haja menção expressa a este nexo. Isto por outro lado, permite a isenção da responsabilidade por parte do comodatário se este provar que o perecimento por caso fortuito teria ocorrido independentemente da violação contratual, embora sendo culpado, isto é, a violação contratual perde sua importância. ${ }^{41}$

$35 \mathrm{O}$ art. $1.805, \S 2^{\circ} \mathrm{CC}$ italiano carrega, porém, uma omissão, que já vem se repetindo desde o art. $1.809 \mathrm{CC}$ italiano de 1865 , ao se referir apenas ao perecimento, e não a deterioração. Trata-se, na realidade, de uma omissão indesejada que ainda não foi sanada do texto legal, segundo BRUNORI, Ernesto. op. cit., p. 24-25. Correto, neste sentido estava o direito romano ao utilizar o termo "periculum".

36 BORSARI, Luigi. op. cit., p. 107-110 (= §3964), narra o exemplo de Tício que não devolve o cavalo no dia primeiro de janeiro, o dia convencionado, mas permanece com ele ainda no dia 31 do mesmo mês. Estando o cavalo em sua estalagem à sua disposição, enquanto deveria estar nestas condições com o proprietário, e ao cair um raio sobre esta, matando não-somente o cavalo emprestado, mas todos os animais nela presentes, configura sua responsabilidade. O raio em si não representa culpa nenhuma por parte do devedor, mas a culpa já tinha ocorrido por deter o cavalo além do prazo previsto. A devolução do cavalo emprestado evitaria o infortúnio, uma vez que o raio apenas atingiu a estalagem de Tício e não outra. Assim, o "caso" em si não vem a configurar como um requisito para a caracterização da hipótese, mas sim a presença da culpa do comodatário, presente, por extensão, desde o momento de violação do contrato.

37 BORSARI, Luigi. op. cit., p. 107-110 $(=\S 3.964)$.

38 BEVILAQUA, Clóvis. op. cit., p. 436-437. Trata-se de um efeito comum decorrente dos arts. 956 e 957 $\mathrm{CC} / 1916$, permitindo ao comodatário afastar sua responsabilidade agravada se provar que o dano aconteceria mesmo se não estivesse em mora. A especialidade deste caso no comodato é a arbitragem de um aluguel pelo comodante, conforme o art. $1.196 \mathrm{CC} / 1916$, a partir do momento em que o comodatário deixa de restituir a coisa, configurando sua mora.

39 BAUDRY-LACANTINERIE, Gabriel; WAHL, Albert. op. cit., p. 366-369 (=ns. 644-647).

40 Quanto ao "caso" existe um importante parecer em MIRANDA, Francisco Cavalcanti Pontes de. Tratado de direito privado: direito das obrigações: obrigações e suas espécies - fontes e espécies de obrigações. 2. ed. Rio de Janeiro: Borsoi, 1958. t. 22, p. 186-187, onde se discute da necessidade de o caso fortuito ou a força maior serem o mesmo caso fortuito ou a mesma força maior para que se excluísse responsabilidade do devedor em mora.

41 BAUDRY-LACANTINERIE, Gabriel; WAHL, Albert. op. cit., p. 366-369 (= n. 644-647). O embasamento deste posicionamento também se encontra no art. 1.302 do CC francês, que genericamente define as bases da responsanilidade e de sua exclusão no caso de demora de restituição da coisa emprestada. O cavalo emprestado para fazer certa viagem, é utilizado pelo comodatário, após a realização desta, para uma outra viagem, ou 
Assim, a opinião de Agostinho Alvim ${ }^{42}$ de que a mora seria uma hipótese de responsabilidade objetiva, por exceção à regra geral, parece descabida frente à maioria da doutrina. ${ }^{43}$

Julius Ritter Staudinger e Karl Kober ${ }^{44}$ sustentam que, dentre as limitações ao uso, a única qualificada como positiva, é a proibição de realizar um outro uso diverso com a coisa emprestada, que seja diferente daquele previsto no contrato, seja expressamente, seja implicitamente. Isto depende da vontade das partes, uma vez que o $\S 603$ do BGB realiza uma determinação normativa específica para esta, proibindo duas condutas específicas do comodatário.

Aqui o uso moderado da coisa serve como padrão estabelecido, sendo que o que é chamado de uso contrário ao convencionado deve ser analisado em cada caso concreto, onde é possível eleger, como uma violação peculiar da convenção, aquela que viola os interesses das partes.

quando se empresta o cavalo para que este trabalhe por oito dias, e o continua a utilizar indefinidamente. O animal é, no primeiro caso, utilizado para um outro uso que não aquele emprestado e, no segundo caso, por tempo além do permitido. Caso o cavalo venha a perecer por um caso fortuito, deve-se analisar em qual circunstância este veio a perecer. Se for por um raio do céu, será o comodatário responsável, uma vez que o animal não teria sido vítima do caso fortuito caso os limites contratuais tivessem sido respeitados. Mas caso pereça subitamente por uma doença que o teria feito perecer aonde quer que esteja, não será responsável. Este posicionamento foi discutido, e muitas vezes se defendeu que o art. 1.881 do CC francês transfere para o comodatário a responsabilidade por todos os casos fortuitos indistintamente, mesmo daqueles que não tiverem qualquer nexo ou liame com a violação contratual havida. Mas, a lei francesa, embora com semelhante rigor, permite freqüentemente que o comodatário use da coisa para além dos limites contratuais, se pensar que o comodante não desaprovaria sua conduta, como admite o art. 322 do Schweizerisches Zivilgesetzbuch. O rigor da lei se apresenta na realidade na ausência de necessidade de uma intimação, vale dizer, o comodatário que utiliza da coisa emprestada fora da época ou do uso convencionados é responsável pelo caso fortuito, mesmo enquanto ainda não foi ultimado de sua situação. Segundo Gabriel Baudry-Lacantinerie e Albert Wahl, para o raciocínio, o importante é não confundir esta hipótese com aquela em que o comodatário, por qualquer motivo, é conduzido a guardar a coisa para além do tempo determinado, mas sem dela se utilizar. A violação dos limites contratuais e a razão pela qual o comodatário se torna responsável pelo caso fortuito estão justamente no fato dele ter se servido da coisa para um outro uso diferente daquele convencionado ou por ter usado a coisa além do tempo fixado. A lei, infelizmente, é omissa quanto à hipótese do comodatário, depois de ter usado a coisa segundo o contratado, guardar a coisa para além do tempo fixado, mas sem continuar a servir da coisa, vale dizer, uma hipótese em que nada haveria para censurar o comodatário além de um atraso na restituição. Esta hipótese segue as regras do art. 1.302 do CC francês, perante a qual o comodatário somente será responsável pelo fortuito a partir do momento em que teria sido intimado a restituir a coisa.

42 ALVIM, Agostinho. op. cit., p. 196-199, 287 (= ns. 149 e 192).

43 BORSARI, Luigi. op. cit., p. 107-110 (= § 3964), que sustenta que nesta hipótese existe um fortalecimento da presença da culpa, sendo que, para a preservação da justiça, exige-se que todos aqueles que causarem um dano a outrem, e que poderiam o ter evitado, devem o indenizar.

44 KOBER, Karl; STAUDINGER, Julius Ritter. op. cit., p. 644-645 (= § 603). 
Assim, a análise do conteúdo e extensão desta limitação ao uso deve ocorrer após a aferição do modo e do propósito determinado empregado no uso da coisa emprestada. ${ }^{45}$

Entretanto, toda esta regra pode vir a se transformar de acordo com a essência da relação jurídica que envolve as partes como juridicamente não-exigível, especialmente se o comodante apresenta no uso conferido ao comodatário claro interesse.

Portanto, a grande discussão sobre o uso diverso diz respeito à permissão do "uso presumido" por decorrência dos laços de amizade entre as partes, pelos quais pode-se dizer que à circunstância do comodante autorizar certo uso, sem este derivar do contrato ou da natureza da coisa emprestada, deve ser tomada com cuidado, pois relativiza a regra. ${ }^{46}$

3.2. Do comodato de coisa avaliada e da assunção voluntária do caso fortuito e da força maior: a maximização da responsabilidade do comodatário

\section{Como bem descreve Michel Fragali “la disciplina dell'ipotesi di comodato} di cosa stimata ha potuto essere considerata come anomala" ${ }^{47}$ sendo que esta anomalia, presente no art. 1.806 do CC italiano, decorre da pluralidade de espécies existentes, e plenamente plausíveis, de avaliação, especialmente das denominadas avaliação

45 Id. Ibid., p. 644-645 (= § 603). Exemplos não faltam no mundo moderno, como a possibilidade real de se estipular que um nobre cavalo de montaria emprestado não seja usado como cavalo de campo, que uma faca de operação não seja usada como descascador de batatas ou que uma tesoura para costuras não apare a grama.

46 SANTOS, João Manuel de Carvalho. op. cit., p. 59-61.

47 FRAGALI, Michele. op. cit., p. 214. Conforme CARRESI, Franco. Comodato (diritto civile). cit., p. $692-696$. Na realidade, a avaliação ou estimação, vale dizer, a determinação do valor exato da coisa emprestada, não é essencial para a existência do contrato. A regra é o comodato sem a avaliação do bem a ser emprestado, sendo a sua avaliação uma exceção que juridicamente consubstancia determinados reflexos especiais no contrato, conforme a previsão do art. 1.806 do CC italiano e do art. 1.883 CC francês. Como característica acessória, a avaliação pode ser inserida no comodato, tendo como principal efeito sobre este, a maior responsabilização do comodatário. Com a avaliação ocorre a transferência para o comodatário da responsabilidade pelo perecimento da coisa emprestada, mesmo se for por fato à ele não imputável, vale dizer, mesmo se decorrentes daqueles eventos chamados de caso fortuito ou de força maior. De fato, uma vez realizada a avaliação ou estimação o comodatário responderá pelo perecimento fortuito, mas se não realizada, segue-se a regra res perit domino, e o comodante arcará com os riscos da coisa. Em complementação, TAMBURRINO, Giuseppe. op. cit., p. 994-1.006, demonstra que a realização da avaliação é regra especial, pois na sua ausência segue-se a regra res perit domino, e o comodante, não o comodatário, arcará com os riscos da coisa. No mesmo sentido BORSARI, Luigi. op. cit., p. 112-113 (= § 3.966), considera esta uma hipótese “anômala" porque esta detém uma singulariedade decorrente do próprio princípio que reparte os riscos entre as partes e intrinsicamente ligada a criação de um objeto de valor. 
"taxationis causa" ou avaliação "demonstrationis causa", considerada "praesumptio iuris et de iure" ${ }^{48}$, e a avaliação "venditionis causa" ${ }^{49}$

A avaliação "demonstrationis causa" não apresenta o objetivo de inverter legalmente o risco, mas demonstra uma grande utilidade prática no contrato, já que sua importância está em determinar, por um lado, objetivamente a responsabilidade do comodatário, e claramente enunciando, por outro lado, que, mesmo no caso de deterioração dolosa ou culposa, o comodatário somente responderá até o preço avaliado.

Tão auto-explicativa como a anterior, a avaliação "venditionis causa" configura exatamente a transmutação do comodato em compra e venda, ou seja, o preço avaliado não somente estabelecerá o limite da responsabilidade do comodatário, como também o valor que pago pelo comodatário o transformará em autêntico proprietário. ${ }^{50}$

Afastadas estas duas hipóteses de anomalia, o desejo legal foi o de deduzir que, realizada a avaliação, as partes voluntariamente teriam decidido transferir o risco, isto é, transmutar a responsabilidade natural do comodante pelo "caso" para a

48 V. FRAGALI, Michele. op. cit., p. 214-216.

49 Um dos defensores desta conceção é BORSARI, Luigi. op. cit., p. 112-113 (= § 3.966), que sustenta que pelo simples fato de oferecer o preço avaliado o comodatário adquire a coisa como sua, vale dizer, sem ao menos atentar para o corpo que lhe foi entregue ou ao uso a que se destinava, a presença da avaliação radicalmente transforma o comodato em uma compra e venda. O benefício dessa transfiguração não está na possível ou aparente vantagem que seria conferida ao comodatário, mas sim na própria necessidade de segurança exigida pelo sistema. O argumento para esta necessidade de segurança é preciso: quando se confere o uso de um objeto de grande valor para o comodatário, existe sempre o perigo de transferência da propriedade por parte do comodante para terceiros, que facilmente reclamariam a coisa baseados na boa-fé. Ao assumir o periculum rei, o comodatário automaticamente assumi a posição de comprador, sendo o legislador muito claro sobre seu desejo no art. 1.811 do CC italiano de 1865 revog. Em outros termos, uma vez estando à cargo do comodatário os efeitos de qualquer desgraça que venham a atingir a coisa, e ele apenas irá devolver o preço avaliado, a transformação na compra e venda não é apenas conveniente, como permite que o sistema não entre em contradição, vale dizer, sarcásticamente, que o comodatário está destinado a pagar o preço avaliado, tendo cometido o único erro de ter avaliado a coisa.

50 A análise ou não se poderia se chamar de "contrato irregular", quando a avaliação pretendesse transferir o domínio não merece atenção, no entendimento de FRAGALI, Michele. op. cit., p. 214-216. Em regra, a coisa objeto do comodato pode tanto ser fungivel como infungivel. O exemplo mais célebre é o do comodato ad pompam, que confere muito mais uma característica de infungibilidade do que de inconsumibilidade, embora esta seja resultado inexorável daquela, pois, quando as partes conferem a infugibilidade, esta sempre comporta a inconsumibilidade, uma vez que não é possível sustentar que a coisa pode ser consumida, mas deve ser restituída in individuo. Assim, não é de se estranhar que coisas fungiveis sejam objeto de comodato, se o comodatário for obrigado a não-consumi-la e restituí-la in individuo. Retirando este caso, não é possível compatibilizar a fungibilidade da coisa com o caráter do comodato. O chamado comodato irregular ou impróprio, o qual tem como característica a infungibilidade limitada ao gênero, vale dizer, uma fungibilidade na espécie, não está presente no Direito italiano. Neste caso, de infugibilidade do gênero, poderia se falar sempre da eadem res, ou seja, a repetição de uma mesma coisa dentro no gênero. O motivo é a contastação de que nem sempre é certo que uma coisa seja, ao mesmo tempo econômica e juridicamente igual a outra dentro do mesmo gênero. Além disso, é inadmissível que a propriedade determinada do comodante, torne-se uma propriedade sobre coisa indeterminada. Por fim, o chamado comodato irregular ou impróprio não é nada mais que um contrato de mútuo. 
responsabilidade agravada do comodatário, levantando a questão se esta transferência seria uma "praesumptio iuris tantum" ou uma "praesumptio iuris et de iure".

$\mathrm{Na}$ defesa da primeira, Michel Fragali, ${ }^{51}$ ataca expressamente Ernesto Brunori $^{52}$ que sustenta a configuração de uma presunção absoluta, através da justificativa que a própria lei deveria ter previsto expressamente a possibilidade do comodatário realizar a prova contrária.

Para Michel Fragali, ${ }^{53}$ esta divergência funda-se em uma análise errônea da coordenação existente entre os arts. 1.806 e $2.728, \S 2^{\circ}$ do CC italiano, praticamente invertendo a mens legis deste último.

Embora a omissão, esta não significa uma omissão da previsão desta prova, uma vez que não se aplica o art. $2.728, \S 2^{\circ}$ do CC italiano, da extrema disponibilidade da matéria, e da inutilidade de se mencionar esta prova, isto é, a certeza de se tratar de uma "praesumptio iuris tantum" seria a falta de sentido de alocar uma presunção genérica do art. 1.806 do CC italiano como uma "praesumptio iuris et de iure" enquadrada no art. $2.728, \S 2^{\circ}$ do CC italiano.

Em suma, a defesa de Michel Fragali ${ }^{54}$ é da presença desta prova no ordenamento, do caráter disponível da matéria, da vontade de transferência dos riscos, e da coordenação do texto legal, especialmente a relação dos arts. 1.806 e $2.728, \S 2^{\circ}$ do CC italiano. ${ }^{55}$

Em um mesmo sentido, porém mais restrito frente ao campo de realização da prova, para Franco Carresi ${ }^{56}$ a realização da avaliação seria suficiente para responsabilizar o comodatário pelo caso fortuito ou de força maior que cause o perecimento da coisa emprestada. Porém, uma vez realizada e perecida a coisa, seria permitida a prova, por parte do comodatário, que se destine a comprovação de que as partes procederam a avaliação da coisa emprestada com o único objetivo de determinar antecipadamente a extensão do dano devido por ele.

\footnotetext{
FRAGALI, Michele. op. cit., p. 214-216.

BRUNORI, Ernesto. op. cit., p. 26-27.

FRAGALI, Michele. op. cit., p. 214-216.

FRAGALI, Michele. op. cit., p. 214-216.

Id. Ibid., p. 214-216. Consiste a prova em contrário na demonstração por parte do comodatário que, ao invés de determinar o valor da coisa, as partes almejavam algo diferente do desejo legal de transferir os riscos, como, por exemplo, o desejo de calcular os danos à serem ressarcidos no caso de perecimento da coisa por culpa ou dolo do comodatário ou de conferir ao comodatário o poder de escolher entre a devolução da coisa e o pagamento de seu valor. $\mathrm{O}$ art. $2.728, \S 2^{\circ}$ do $\mathrm{CC}$ italiano declara que qualquer presunção admite prova em sentido contrário, salvo aquelas em que a lei declara certos atos nulos e não admite ação em juízo. Mesmo nesta ressalva, a declaração de que certos atos são ungidos pela nulidade e de que a lei não admitiu a ação em juízo podem admitir a prova contrária se a lei a conferir. Assim, a prova em sentido contrário é a regra e não a exceção, presente em todos os casos tacitamente, sendo apenas necessária sua previsão expressa na ressalva legal aos atos nulos e da não-admissão da ação em juízo.

56 CARRESI, Franco. Comodato (diritto civile). cit., p. 692-696.
} 
Entretanto, Ernesto Brunori ${ }^{57}$ entende que a regra deve ser observada a partir de uma construção histórica da hipótese, baseada em Ulp. 28 ad. ed., D. 13, 6, 5, 3. ${ }^{58}$

A primeira tentativa de elucidar este texto enxergava que esta era uma hipótese de agravamento automático da responsabilidade do comodatário, porém a interpretação dominante visualizou, através da expressão "se praestaturum recepit", a presença de um pacto especial para que ocorresse a avaliação, e do qual constaria o pagamento do preço estimado da coisa emprestada, mesmo se o perecimento ocorresse por fortuito. ${ }^{59}$

Esta última tonrar-se-ia um tanto inexata e irracional, levando RobertJoseph Pothier ${ }^{60}$ a erroneamente afirmar que se trata de proposição inaplicável, a menos que as partes não tivessem expressamente previsto que a avaliação implica-se na assunção do risco por qualquer acidente.

Por sua vez, o art. 1.806 do CC italiano traz uma redação considerada tão obscura e enigmática, como aquela que o fragmento romano possui, sucitando os mesmos problemas, mas se aceita que na avaliação estaria implícita uma "convenzione di assunzione

BRUNORI, Ernesto. op. cit., p. 26-27.

58 Sobre o fragmento deve-se observar o raciocínio desenvolvido por BORSARI, Luigi. op. cit., p. 112-113 (= § 3.966), segundo o qual três sistemas foram criados para justificar esta hipótese de responsabilidade agravada. Pelo primeiro sistema, a avaliação possui um único objetivo que é o de estabelecer um valor pelo qual o comodatário se obriga frente a qualquer evento que ocorrer com a coisa, devendo ou a restituir ou restituir seu valor. Não restam dúvidas que, seja o perecimento decorrente de caso fortuito, seja decorrência da vontade do devedor, e caso não fosse possível a restituição da coisa emprestada, o valor estimado é que deveria ser devolvido. A avaliação prometida acrescente uma outra obrigação, a qual impõe plenamente ao comodatário o periculum, ou seja, de nada adiantaria a avaliação se não impussese ao comodatário todos os riscos derivados da coisa, uma vez que é ele que detém o interesse sobre o uso, devendo, portanto, se responsabilizar pela máxima diligência. A contribuição deste sistema foi determinar o efeito mais notório e importante da avaliação, isto é, a transferência dos riscos. O segundo sistema, que parte do anterior, mas o critica ardentemente, afirma que se trata de excessiva consideração a hipótese, conferir à avaliação a transferência dos riscos como um efeito natural e próprio de sua estrutura. A avaliação não pode ser tomada como um sinônimo de transferência dos riscos, mas como uma medida ligada umbilicalmente à causa do contrato, determinando o quanto irá se pagar, independentemente do evento que vier a ocorrer. Para que ocorra a transferência de riscos é necessário que exista uma declaração ou um ato que adicione este efeito, ou seja, uma intenção inegavelmente manifesta por uma convenção. Como contribuição, o segundo sistema demonstra que a avaliação não se refere apenas à transferência dos riscos, mas também a um nivelamento da responsabilidade do comodatário. Entretanto, uma convenção desta forma seria repugnante, pois, através de sua própria vocação ingênua, o comodato se transformaria em uma locação. Havia a necessidade de uma terceira interpretação, infelizmente também errônea. O "periculum" englobaria apenas ao perecimento decorrente da culpa do comodatário, e não como decorrência do caso fortuito, indicando que qualquer dano decorrente da culpa do comodatário deve ser reparado. A interpretação da opinião de Ulpiano sobre o "omne periculum" é que a expressão apenas englobaria a culpa, mesmo que se referisse a levissima. Trata-se de uma interpretação muito restrita, por não compreender a existência de uma avaliação sem a co-existência da culpa por parte do comodatário, o que qualquer jurista, em uma leitura atenta de Ulpiano refutaria.

59 BRUNORI, Ernesto. op. cit., p. 26-27. Equivaleria, assim, a presença deste pacto à assunção dos riscos. O preço estimado, que realmente adossa ao comodatário a responsabilidade pelo fortuito, não poderia ser presumido, mas o pacto especial poderia não ser expresso e dedutível das circunstâncias. POTHIER, Robert-Joseph. op. cit., p. 21 (= n. 61). 
di rischio" por parte do comodatário, para todos os possíveis casos de perecimento que a coisa emprestada viesse a sofrer.

A partir da defesa de E. Brunori ${ }^{61}$ sobre a constituição de uma "praesumptio iuris et de iure", Gabriel Baudry-Lacantinerie e Albert Wahl ${ }^{62}$ afirmam que as partes realizam a avaliação apenas com a intenção de determinar um montante indenizatório, e que caso a coisa venha a perecer por culpa do comodatário, este terá de ressarcir neste valor o comodante.

O real sentido da cláusula é dizer que a avaliação significa que o perecimento da coisa emprestada, seja por culpa do comodatário, ou seja, pelo "caso", obriga o comodatário a uma indenização cujo valor já foi previamente fixado no momento de conclusão do contrato.

Assim, o entendimento que tem prevalecido é o de que quando não houver avaliação, a prova do fortuito está a cargo do comodatário, para que este se isente de sua responsabilidade. Porém, quando existir, a prova do fortuito de nada valerá, uma vez que - retoricamente - o fortuito, na realidade, não existe, ${ }^{63}$ configurando-se uma hipótese de responsabilidade agravada objetiva.

Assim, o caráter singular e especial da avaliação está em seu fundamento, vale dizer, de mais nada serviria as demais hipóteses de responsabilidade agravada do comodatário, uma vez que a avaliação detém uma essência niveladora da responsabilidade do comodatário ${ }^{64}$ pelo limite avaliado ou preço avaliado, ou, ao o que se denomina, em italiano, de "debito di valuta". ${ }^{65}$

Justamente por trazer este efeito e da proximidade da avaliação com a cláusula de assunção dos riscos, algumas condições foram colocadas para a autenticidade de sua disposição ${ }^{66}$ devendo ser, antes de tudo, voluntária, ${ }^{67}$ porque depende da vontade de ambas as partes para se caracterizar e de seu esforço na realização da perícia.

Entretanto, não basta a inserção de uma cláusula qualquer que passa despercebida pelas partes, como, por exemplo, "vi presto i miei cavalli cha valgono mille lire", 68 que seria insuficiente e acidental, por não demonstrar nem uma consistência de

${ }_{61}$ BRUNORI, Ernesto. op. cit., p. 26-27.

62 BAUDRY-LACANTINERIE, Gabriel; WAHL, Albert. op. cit., p. 363-364 (= n. 639).

63 BARBIERI, Ezio Maria; NAPOLETANO; Vicenzo; NOVITÀ, Mario. op. cit., p. 381-384. No mesmo sentido, BORSARI, Luigi. op. cit., p. 112-113 (= § 3.966).

${ }^{64}$ LA FARINA, Cesare. op. cit., p. 308-313.

${ }_{65}$ Para LA FARINA, Cesare. op. cit., p. 308-313, o "debitto di valuta" tem a única e excluiva função de transferir ao comodatário os riscos pelo perecimento derivados do caso fortuito ou da força maior.

66 BORSARI, Luigi. op. cit., p. 112-113 (= § 3.966).

67 Cf. BORSARI, Luigi. op. cit., p. 112-113 (= § 3.966). Neste sentido, também PLANIOL, Marcel [et al.]. op. cit., pp. 110-111 (= § 1131), que se refere a natureza convencional da avaliação, vale dizer, não pode ser esta imposta por uma das partes.

68 V. BORSARI, Luigi. op. cit., p. 112-113 (= § 3.966). 
cláusula expressa sobre a avaliação, nem a presença do trabalho dos peritos que tenham examinado cada elemento que compõe a coisa emprestada, e que corre o risco de não ser percebida ou notada pelas partes.

A contrário sensu, é necessária a presença de uma cláusula solene, que além de dever apresentar plena autonomia no contrato, demanda um exame pericial para cada elemento ou parte que compõe a coisa emprestada, sendo adequadamente construída por um enunciado simples, mas não-incidental, como: "voi mi restituirete a qualunque evento la cosa prestata nel valore convenuto di lire 500" ,69 já que após a realização da perícia, uma cláusula simples como esta seria o suficiente para caracterizar a avaliação, e demonstra que se almeja a devolução do valor, e não do corpo. ${ }^{70}$

Além do caráter voluntário - que é um benefício concedido ao comodante-, a segunda condição para que a avaliação seja válida se deve ao respeito de sua limitação temporal, ou seja, deve ocorrer durante a vigência do contrato ou, mais precisamente, em sua formação, não tendo nenhum efeito a avaliação realizada posterior. ${ }^{71}$

No Direito Civil brasileiro, por falta de um dispositivo que tratasse especificadamente desta hipótese, como ocorre nos ordenamentos italiano e francês, Agostinho Alvim ${ }^{72}$ entende que a assunção de riscos deve ser expressa, pois consentimento tácito é inoperante, conforme arts. 1.058 e 1.079 CC/1916 revog. Assim, mesmo que seja possível - e até comum - a avaliação da coisa emprestada, o principal efeito desta - a transferência de todos os riscos para o comodatário -, somente seria possível com uma "estipulação expressa", ou contrário do que ocorre com parte dos ordenamentos jurídicos, pelos quais a regra na avaliação é a assunção tácita da transferência dos riscos, sendo que estes somente seriam afastados, através de uma cláusula em sentido contrário.

A hipótese da assunção voluntária [dos riscos derivados] do caso fortuito e da força maior é considerada por Arnoldo Medeiros da Fonseca, ${ }^{73}$ como uma - entre

69 Cf. BORSARI, Luigi. op. cit., p. 112-113 (= \$ 3.966).

70 A favor da defesa da necessidade de uma perícia na hipótese de comodato de coisa avaliada, v. BORSARI, Luigi. op. cit., p. 112-113 (= § 3966). Em sentido contrário, pela desnecessidade de uma perícia, como também pela insuficiência de uma indicação incidental, v. FRAGALI, Michele. op. cit., p. 214-216. Para este último, basta que a avaliação seja clara e específica.

71 BORSARI, Luigi. op. cit., p. 112-113 (= § 3.966), não se pode afirmar que o "patto in contrario" - aquele capaz de afastar a assunção dos riscos pelo comodatário - se refira à validade da avaliação. Pelo contrário, somente se refere à validade da assunção dos riscos. Neste terreno dispositivo, FRAGALI, Michele. op. cit., p. 214-216, diz que nada impede que a avaliação refira-se apenas aos riscos pela deterioração, uma vez que o risco pela deterioração é mau menor, se comparado com o risco pelo perecimento. Esta possibilidade de haver a transferência dos riscos quanto à deterioração se concretizaria quando, por exemplo, se indica a proporção em que a diminuição de utilidade da coisa incide sobre o preço estimado, e o comodatário deverá suportar a diminuição do preço estimulado quando cada grau de utilidade for decaindo.

72 ALVIM, Agostinho. op. cit., p. 335-337 (= n. 209).

73 FONSECA, Arnoldo Medeiros da. op. cit., p. 174 
as duas listadas pelo autor - das hipóteses que podem ser consideradas como exceções autênticas ao efeito liberatório do "caso".

Por esta exceção ao princípio "res perit domino", o comodatário assume voluntariamente a responsabilidade pelo "caso"74 adicionando um pacto ou cláusula expressa embutida no contrato. ${ }^{75}$

A partir deste momento, não há mais o que ser discutido acerca de sua culpa, ou de qualquer outro critério, já que toda controvérsia já foi sanada antes mesmo de ter sido iniciada, vale dizer, a presença de uma cláusula expressa de assunção dos riscos cerceia qualquer questionamento. ${ }^{76}$

Michel Fragali relaciona ${ }^{77}$ a assunção voluntário do caso fortuito e da força maior com o mais importante efeito da possível caracterização de uma obrigação alternativa, uma vez que na ocorrência de determinado evento a devolução da coisa emprestada in individuo não seria possível, podendo até transformar o comodato em um mútuo condicional. ${ }^{78}$

Como demonstra Agostinho Alvim, ${ }^{79}$ conforme o art. 1.058 do CC/1916 revog., o devedor pode assumir os riscos do caso fortuito, desde que seja expressamente, pois consentimento tácito é inoperante, segundo os arts. 1.058 e 1.079 do CC/1916 revog. ${ }^{80}$ devendo ser seguido o princípio de que em todo o assunto envolvendo o risco do devedor deve ser utilizada uma interpretação restritiva. Há dúvida de haver ou-não um pacto que envolva esta matéria, resolve-se em sentido negativo ou, na dúvida da extensão deste, resolve-se por restringi-lo em benefício do devedor. ${ }^{81}$

Por tudo o que foi exposto, a assunção voluntária do caso fortuito ou da força maior pode ser considerada como a maximização da responsabilidade não somente do comodatário, como de qualquer devedor, ${ }^{82}$ podendo incluir, segundo o entendimento de alguns, ${ }^{83}$ até a força maior.

DIAS, José de Aguiar. op. cit., p. 24-26.

BORSARI, Luigi. op. cit., p. $111(=\S 3965)$.

${ }^{6}$ Id. Ibid. Assim, a imputação da responsabilidade será imediata e objetiva.

77 FRAGALI, Michele. op. cit., p. 188-189.

78 Id. Ibid., caso em que a coisa emprestada é transformada e o comodante poderá exigir uma coisa nova, mesmo se dessa o comodatário não detiver a propriedade.

79 ALVIM, Agostinho. op. cit., p. 335 (= n. 209).

80 Não há porque se cogitar em um entendimento diferenciado frente ao Novo Código Civil brasileiro.

81 ALVIM, Agostinho. op. cit., p. 335 (= n. 209). Esta é a regra, salvo casos especiais.

82 ALTAVILLA, Enrico. Forza maggiore e caso fortuito. Nuovo Digesto Italiano, Torino, v. 16, 1938, p. 118.

83 Cf. TARDIVO, Carlo-Maria. Studi sul « commodatum ». Archivio Giuridico "Filippo Serafini", Modena, v. 204, 1983, p. 87-90. 
4. A hipótese clássica do princípio do sacrifício da coisa própria

\section{1. Aspectos preliminares}

Dentre as hipóteses de inversão legal do risco, o princípio de sacrifício da coisa própria é a mais polêmica entre a doutrina. ${ }^{84}$

Trata-se da hipótese clássica pela qual o comodatário responde agravadamente, ${ }^{85}$ sendo prevista, seja expressamente ou-não, nas principais legislações do mundo ${ }^{86}$ e a qual poderia ser traduzida, genericamente, como a responsabilidade do comodatário pelo perecimento da coisa emprestada por um caso fortuito no qual podia salvá-la sacrificando uma própria, ou se, podendo salvar as duas, preferiu esta última. ${ }^{87}$

Gabriel Baudry-Lacantinerie e Albert Wahl ${ }^{88}$ sustentam que se tratam de duas condutas distintas, uma através da qual o comodatário usa da coisa emprestada, para não sacrificar a própria, e outra em que ambas as coisas correm risco de perecer devido ao mesmo caso fortuito, devendo o comodatário executar, nesta última, uma escolha.

Embora as principais codificações, todas com textos muito semelhantes, refiram-se à duas vertentes do princípio de sacrificio da coisa própria, o Direito Civil brasileiro apenas descreve uma destas, seja o art. $1.253 \mathrm{CC} / 1916$ revog., seja o art. 583 $\mathrm{CC} / 2002{ }^{89}$

A real diferença das duas vertentes encontra-se na constatação de que na primeira

$\overline{84}$ FRAGALI, Michele. op. cit., p. 216. É passível de questionamento se esta hipótese configura-se ou não como um autêntico princípio jurídico. À favor encontra-se BORSARI, Luigi. op. cit., p. 111 (= §3965): " $E$ una legge d'alta moralità. Il principio é questo, 'che il comodatario è responsabile della perdita della cosa prestata quando egli avrebbe potuto salvarla in luogo della sua propria"', como também CARRESI, Franco. Il comodato - Il mutuo. cit., p. $62-63(=\S 40)$ e TAMBURRINO, Giuseppe. op. cit., p. 994-1.006. Contra BEVILAQUA, Clóvis. op. cit., p. 437. Existem também os que se referem ora como princípio, ora como regra. V. FRAGALI, Michele. op. cit., p. 216-217. E aqueles, como FERRARIO, G. A. op. cit., p. 385-405, que utilizam o termo "máxima". Devido à flexibilidade decorrente da aplicação do dispositivo aos casos concretos, bem como ao próprio comportamento imposto ao comodatário, conforme GONÇALVES, Luiz da Cunha. Tratado de direito civil: em comentário ao Código Civil português. cit., p. 310 (=§1.148), prefere-se o termo princípio.

85 GONÇALVES, Luiz da Cunha. Tratado de direito civil: em comentário ao código civil português. cit., p. $310-316(=\S 1148) \mathrm{e}$ . Princípios de direito civil luso-brasileiro: direito das obrigações. São Paulo: Max Limonad, 1951, v. 2, p. 519-1.075 (= §§ 187-468).

${ }^{86}$ Cf. explicitamente nos art. 1.882 do CC francês, art. 1.810 do CC italino. de 1865 revog., art. $1.805, \S 1^{\circ}$ do CC italiano, art. 1.516, Parágrafo Único do CC português. de 1867 revog., art. 1.253 do CC/1916 revog. e art. 583 do CC/2002, e implicitamente no $§ 603$ do BGB.

${ }_{87}$ TAMBURRINO, Giuseppe. op. cit., p. 994-1.006, e DE RUGGIERO, Roberto; MAROI, Fulvio. Istituzione di diritto privato: diritto di obbligazione e contratti - tutela dei diritti. 6. ed. Messina: Giuseppe Principato, 1947. v. 2, p. $359(=\S 163)$. Quanto a discussão da possibilidade de exclusão da responsabilidade do comodatário por força maior v. item 4. 4.

88 BAUDRY-LACANTINERIE, Gabriel; WAHL, Albert. op. cit., p. 364-366 (= n. 640-643).

89 V. cap. Item. 4. 4. sobre a previsão de apenas uma das vertentes no Direito brasileiro. 


\section{o comodatário seria juridicamente responsável pela substituição de uma coisa emprestada} em perigo por uma pessoal, que não se encontra em perigo, enquanto na segunda existe uma alternativa, onde a escolha deve ser feita entre a coisa emprestada e a coisa do comodatário, ambas em perigo. ${ }^{90}$

90 BRUNORI, Ernesto. op. cit., p. 25. No mesmo sentido, LAURENT, François. op. cit., p. $482-484$ (= n. 474). Um famoso caso que ocorreu na "Corte di Torino" é narrado por MIRABELLI, Giuseppe. op. cit., p. 29-33, que prova não somente a diferença entre as duas vertentes do princípio de sacrificio da coisa própria, como também demonstra seu caráter excepcional, configurado em seu substrato objetivo. Este caso - "Bellia $x$ Vigna" baseia-se sobre o art. 1.810 do CC italiano, de 1865, revog. e é digno de uma atenção especial.

A "Corte di Torino" declarou que a relação jurídica existente entre Bellia e Vigna, duas sociedades italianas, era a de comodato, demonstrada pela primeira empresa, e admitida em recurso pela segunda, figura esta intermediária entre o mútuo e o depósito. Trata-se de um caso de ações de uma sociedade anônima cotadas e negociadas na Bolsa de Valores, sendo que a Vigna cuidava destas ações, 45 ao todo, à título de comodato, sub-rogando a Bellia, e completando sua caução de administração de sua fábrica Sella, um lanifício. A conclusão intuitiva que se teria é que a abstenção de tal sub-rogação por parte da Vigna, tornaria impossível salvar as ações do ônus de serem perdidas, o que violaria o art. 1.810 do CC italiano, de 1865, revog. Trata-se da disposição que imputa ao comodatário o perecimento ocorrido por um caso fortuito, quando este poderia ter utilizado uma própria no lugar da coisa emprestada, ou se, não podendo salvar as duas, preferiu salvar a própria, sendo, em ambos os casos responsável pelo perecimento da outra. Mas esta disposição não foi aceita no caso, pois se sustentou que os preços negociados em uma Bolsa de Valores para os títulos judiciais não são estáveis, e de um momento ao outro pode acontecer que as ações de um empresa comercial passam subir ou descer, não se podendo equiparar este evento a um caso fortuito. Assim, não se aplicaria a sanção imposta no art. 1.810 do CC italiano. de 1865 revog., vale dizer, a inaplicação do art. 1.810 do CC italiano, de 1865 , revog., uma vez que se tratando de títulos industriais seria de sua natureza a oscilação para mais ou para menos, não dependendo, nem para a perda total, de uma ação da Vigna. Até porque a queda do valor dos títulos em uma Bolsa de Valores surge de causas absolutamente estranhas, como a queda do preço da lã. Tudo parece estar incluído no risco e na instabilidade que os sujeitos que vão a Bolsa de Valores se submetem, o que bastava para eliminar o conceito de caso fortuito, sem que se usasse dos efeitos reflexos, como o da crise da lã. Bellia ainda alegava na oportunidade que sobre o art. 1.810 do CC italiano, de 1865, revog., o comodatário não respondia apenas por caso fortuito, mas por qualquer outra hipótese, o que a "Corte di Torino" já havia afastado, bem como a responsabilidade pelos arts. 1.809 e 1811 do CC italiano, de 1865, revog. O comodatário deveria devolver a mesma coisa recebida, mas como a Vigna não podia, ofereceu devolver à Bellia as mesmas ações, embora com preço doiminuído. Assim, a "Corte di Torino" entendeu que a Vigna não deveria devolver ações pessoais que não tinham diminuído o preço, pois não fazia parte da própria natureza do contrato de comodato.

O importante no caso foi a análise que se fez dos termos do princípio de sacrificio da coisa própria. A primeira parte deste expõe a hipótese do sacrifício de uma coisa pessoal quando a coisa emprestada perecesse por um caso fortuito, sendo que, em um segundo momento esboça-se a hipótese de que estando as duas coisa correndo o risco, deveria o comdoatário sacrificar a coisa própria. Ambas hipóteses detém um requisito vital comum, isto é, a ocorrência do caso fortuito. Se este não ocorrer - independentemente em qual vertente do princípio - a hipótese não se caracteriza, afastando-se do comodatário a responsabilidade pelo evento. Ao caso, então, acabou por não ser aplicado o art. do 1.810 CC italiano, de 1865 , revog. pela simples constatação que seria um erro jurídico reconhecer o caso fortuito onde este não existia.

Entrementes, deixa-se claro que não é somente quando a coisa emprestada perece por um caso fortuito que estará o perecimento a cargo do comodatário. Isto está demonstrada, uma vez que a "Corte di Torino" analisou primeiramente os arts. 1808, 1809 e 1811 do CC italiano, de 1865, revog., excluindo qualquer outra responsabilidade da empresa comodatária Vigna. Logo, o dilema do caso iria por se focar em uma regra absolutamente pragmática. Se o perecimento veio a ocorrer por caso fortuito, deveria se aplicar o art. 1.810 do CC italiano, de 1865 , revog., mas, se o perecimento veio a ocorrer, mas não por caso fortuito, deveria se analisar as outras hipóteses concretas de responsabilidade do comodatário previstas na lei, e que dependeriam de uma culpa por parte do comodatário. A Bellia não encontrava no momento algum argumento que poderia 
Embora Robert-Joseph Pothier ${ }^{91}$ o tenha encontrado muito antes, de uma maneira geral, os fundamentos do princípio de sacrificio da coisa própria ${ }^{92}$ vêm sendo debatidos pela doutrina desde o Direito Romano, assim como sua pertinência, ${ }^{93}$ como a seguir se verá.

\section{2. A construção da hipótese no Direito Romano: Ulp. 28 ad ed., D. 13, 6, 5, 4}

O princípio de sacrificio da coisa própria enuncia uma hipótese em que o caso fortuito não vem a exonerar o comodatário da responsabilidade que este detém frente ao comodante, ${ }^{94}$ sendo que toda sua discussão já se encontrava no fragmento de Ulpians a seguir examinado.

Ulp. 28 ad ed., D. 13, 6, 5, 4

Quod vero senectute contigit vel morbo, vel vi latronum ereotum est, aut quid simile accidit, dicendum est nihil eorum esse imputandum ei qui commodatum accepit, nisi aliqua culpa interveniat proinde et si incendio vel aliquid damnum fatale, non tenebitur, nisi forte, cum possit res commodatas salvas facere, suas praetulit.

Não deve ser imputado ao comodatário os acontecimentos que ocorrem por velhice ou por doença, ou mesmo quando a coisa é arrebatada por força de ladrões, ou se algo semelhante aconteceu, salvo se [o comodatário] não intervir com alguma culpa. Portanto, [o comodatário] não estará obrigado se algo acontecer [à coisa emprestada] por incêndio, por ruína ou

utilizar, pois todos as previsões sobre o comodato nos arts. 1.805, 1.806, 1.809 e 1.811 do CC italiano, de 1865 , revog. foram afastados pela "Corte di Torino". A lei é clara, pois o art. 1.810 do CC italiano, de 1865 , revog. se aplica somente quando a coisa perece por caso fortuito. O que a recorrente Bellia desejou é que este dispositivo fosse aplicado sempre que o comodatário tivesse uma coisa pessoal hábil a substituir a coisa emprestada, sendo que esta coisa pessoal estivesse no patrimônio do comodatário. Esta seria uma interpretação muito extensiva do dispositivo, que a própria lei limitou a ocorrência de um evento classificado como caso fortuito, e que levaria a uma procura por parte do comodatário de uma coisa a substituir a coisa emprestada sempre que esta estivesse em risco.

Logo, para a ocorrência da primeira vertente deste princípio pressupõe, em primeiro lugar, a configuração de um caso fortuito, e, em segundo lugar, uma coisa que esteja no patrimônio e na disponibilidade do comodatário. A existência da coisa emprestada no patrimônio e na disponibilidade do comodatário também é um presuposto da segunda vertente do princípio, que, além disso, pressupõe a ocorrência do caso fortuito para as duas coisas, própria e emprestada, e não somente para esta última.

91 POTHIER, Robert-Joseph. op. cit., p. 23-24 (= n. 56).

92 FRAGALI, Michele. op. cit., p. 216.

93 Cf. FRAGALI, Michele. op. cit., p. 216-218. V. cap. IV. 3.

94 FERRARIO, G. A. op. cit., p. 385-405. 
por qualquer outro dano fatal, salvo se podendo salvar as coisas dadas em comodato, preferiu as suas. ${ }^{95}$

Assim, G. A. Ferrario, ${ }^{96}$ demonstra que todo o fundamento do princípio de sacrifício da coisa própria, bem como o raciocínio sobre este desenvolvido, nasceu das duas últimas frases deste fragmento de Ulpiano “... cum posset res comodatas salvas facere, suas presulit" "97: éuma máxima do Direito Romano considerada conforme a eqüidade e os ditames da boa-fé, embora não existam dúvidas que o comodatário, no caso concreto, salvará a "res propria" e deixará perecer a "res commodata", pois, caso contrário, teria perdido a própria coisa.

Não se trata propriamente de uma culpa por haver sacrificado a coisa alheia, mas sim por estar contrário à natureza da boa-fé obter um lucro com o sacrifício da coisa emprestada, ${ }^{98}$ uma vez que o comodato é um contrato baseado na gratuidade. ${ }^{99}$

Este entendimento não é o mesmo de Giuseppe Ignazio Luzzatto, ${ }^{100} \mathrm{o}$ qual entende que no período pós-clássico verificou-se a passagem da concepção da responsabilidade objetiva para a de conteúdo subjetivo - "diligentia" . Durante esta transição, também ter se verificado a construção de uma teoria do "casus", evento que exorbita o conteúdo positivo da "diligentia".

95 Texto em latim extraído de KRUEGER, Paulus; MOMMSEN, Theodorus. Corpus Iuris Civilis - Institutiones - Digesta. Dublin: Weidmann, 1973, v. 1, p. 212. Tradução para o português baseada a partir do confronto das traduções, em espanhol, de GARCIA DEL CORRAL, Ildefonso. Cuerpo del Derecho Civil Romano - Institutas - Digesto. Barcelona: Jaime Molinas, 1990, t. 1, p. 739 e D’ORS, Alvaro [et al.]. El Digesto de Justiniano: constituciones preliminares y libros 1-19. Pamplona: Aranzadi, 1968. v. 1, p. 523, e, também, tradução livre. As expressões entre colchetes não pertencem ao fragmento original, mas servem como articuladores na tradução.

96 FERRARIO, G. A. op. cit., p. 385-405.

${ }_{97}$ KRUEGER, Paulus; MOMMSEN, Theodorus. op. cit., p. 212 preferiu a forma “... cum possit res commodatas salvas facere, suas praetulit".

98 Cf. FERRARIO, G. A. op. cit., p. 385-405, que fundamenta o princípio de sacrifício da coisa própria não só na eqüidade, mas também na boa-fé, tendendo a caracterizar a responsabilidade objetiva no princípio de sacrifício da coisa própria. Este último autor também entende que mesmo Direito Civil moderno, não faltam defesas no sentido de que a sanção imposta ao comodatário através do princípio de sacrificio da coisa própria é simplesmente inspirada em um juízo de eqüidade, independentemente do concurso de sua culpa.

99 FERRARIO, G. A. op. cit., p. 385-405. Assim, se o comodatário poderia impedir que a coisa perecesse por um caso fortuito, não pode o comodatário alegar este para liberar-se de sua responsabilidade. A prova que o comodatário poderia evitar o acidente com a coisa emprestada está obviamente no próprio caso, vale dizer, se o comodatário dispôs de tempo e arranjou alguma forma para salvar uma coisa pessoal, também deveria ter encontrado um tempo e arranjado um modo para salvar a coisa emprestada. Esta prova demonstra que o comodatário inadimpliu com sua obrigação de custodiar a coisa emprestada e logo deve arcar com as conseqüências deste inadimplemento. Uma pergunta que não tem dignidade de ser feita e não apresenta qualquer relevância refere-se à hipótese do comodatário salvar a coisa própria em detrimento da alheia, uma vez que a primeira detém valor superior frente a segunda.

${ }^{100}$ LUZZATTO, Giuseppe Ignazio. Caso fortuito e forza maggiore come limite alla responsabilità contrattuale - La responsabilità per custodia. cit., p. 46. 
Mesmo no Direito Romano, a evolução seria sentida no período pós-clássico, encontrando seu substrato no Corpus Iuris Civilis, especialmente no comodato, em Ulp. 28 ad ed., D. 13, 6, 5, 4 onde, se por um lado, é o único fragmento onde se encontra uma teoria do "casus", por outro lado, é onde se encontra a formulação mais completa desta, o que já denotaria uma influência dos compiladores na formulação da responsbailidade do comodatário. ${ }^{101}$

Poderia-se, assim, discutir-se o quanto, neste fragmento de Ulpiano foi alvo de uma interpolação pós-clássica, enquanto trabalho árduo dos compiladores justinianeus.

Não restam dúvidas, no entender de Giuseppe Ignazio Luzzatto, ${ }^{102}$ que Ulp. 28, ad ed., D. 13, 6, 5, 4 tenha passado por uma ampla modificação dos compiladores, pela simples presença da abstração do "damnum fatale", como nos demais fragmentos do mesmo grupo, o que demonstraria uma reelaboração compilatória que teria diretamente modificado os pressupostos da responsabilidade do comodatário, revelando-se uma desmonstração viva da sobreposição da obra dos compiladores justinianeus aos textos dos jurisconsultos clássicos. Estes teriam precedido de forma contrária, pelo menos no tocante a responsabilidade do comodatário, ${ }^{103}$ distinguindo-se, no fragmento de Ulpiano, duas partes nitidamente distintas.

Enquanto que Ulp. 28 ad ed., D. 13, 6, 5, 15 esboça muito bem a solução dos jurisconsultos clássicos, os quais, determinando que o comodatário responda pela "custodia" técnica, por outro lado, sustenta-se que Ulp. 28 ad ed., D. 13, 6, 5, 2-4, representam uma reelaboração justinianéia, empreendida pelos compiladores, que ao inserirem pequenas modificações, transformaram a custódia clássica em uma responsabilidade subjetiva, baseada na culpa e na "diligentia".

Por outro lado, enquanto Ulp. 28 ad ed., D. 13, 6, 5, 2-3 tratariam da responsabilidade subjetiva, Ulp. 28, ad ed., D. 13, 6, 5, 4 criaria uma teórica do "casus", demonstrando a correlação das matérias no âmbito pós-clássico, o que supõe que este fragmento de Ulpiano foi duplamente estratificado - no período clássico e no período pósclássico - pois se relacionaria com a "diligentia", com o "damnum fatale" dos anteriores, e com a "custodiam praestat" de Ulp. 28 ad ed., D. 13, 6, 5, 15. ${ }^{104}$

${ }_{101}$ Id. Ibid., p. 110.

${ }^{102}$ Id. Ibid., p. 110-115. Entretanto, para os jurisconsultos clássicos, as idéias de culpa e de caso fortuito eram totalmente estranha. Assim, pode-se deduzir que a idéia de culpa estava totalmente unida a concepção de caso forutito, que eram conceitos estranhos ao período clássico, o qual, por sua vez, operava conforme os ditames da responsabilidade objetiva, dentro da qual se inseria a fragmento de Ulpiano. Há, portanto, a necessidade de limitar certos contornos particulares da responsabilidade objetiva.

${ }^{103}$ Id. Ibid., p. 135.

${ }^{104}$ LUZZATTO, Giuseppe Ignazio. Caso fortuito e forza maggiore come limite alla responsabilità contrattuale - La responsabilità per custodia. cit., p. 135-136. 
Desta forma, ainda seria possível existir um substrato clássico no texto de Ulpiano, que constituiria uma responsabilidade objetiva, embora de forma tímida. ${ }^{105}$

Raymond-Théodore Troplong ${ }^{106}$ entende que Ulpinao, neste fragmento não exigia a "le superlatif de la vigilance", ${ }^{107} \mathrm{e}$, como observa Luigi Sertorio, ${ }^{108}$ a regra aqui contida teria sido extensamente interpretada, tentando os glosadores introduzir a distinção segundo o valor que detivessem as coisas envolvidas na fattispecie, que deve ser, neste momento, rejeitada. ${ }^{109}$

O posicionamento de que se aplicaria uma "culpa levis in concreto" ao princípio de sacrifício da coisa própria, sendo que em todo caso o comodatário deveria sacrificar a coisa própria, se houvessem meios, diretos e indiretos, de ser salva a coisa emprestada, aceito por autores do mais notório gabarito, surgiu impondo ao comodatário que este protegesse tanto a coisa emprestada como a própria coisa, utilizando para a coisa emprestada a diligência "quam suis rebus adhibere solet", e, caso não a tivesse, seria responsável, porém não pode ser admitido pelo conceito de "culpa levis in concreto" 110 já que a proposição "cum possit res commodatas salvas facere, suas praetulit” não é correlação, nem referência à nenhuma medida concreta de responsabilidade.

Para a correta interpretação do fragmento, dever-se-ia ter em mente seu objetivo - evitar um prejuízo para o comodante -, além de se perceber que, para a caracterização desta hipótese, certos pressupostos são necessários, ${ }^{111}$ o que seria suficiente para demonstrar que o texto de Ulpiano está, na realidade, longe da questão da culpa, existindo, pelo contrário, um substrato inteiramente fático ou objetivo - derivado do período clássico -, o qual pelo simples fato de existir uma possibilidade de salvar a própria coisa com o sacrifício da coisa emprestada seria fonte de responsabilidade.

\footnotetext{
105 Id. Ibid., p. 135-136. Levando em consideração esta advertência que pode ser feita em matéria de responsabilidade objetiva, chegaria-se a conclusão que os compiladores pós-clássicos ou justinianeus deveriam generalizar a fattispecie contemplada por Ulp. 28, ad ed., D. 13, 6, 5, 4, introduzindo alíneas para a complementar como "aut quid simile accidit" e "vel aliquid damnum fatale".

106 TROPLONG, Raymond-Théodore. op. cit., p. 96-101 (n. 113-118).

107 Trata-se de uma crítica direta ao posicionamento de POTHIER, Robert-Joseph. op. cit., p. $23-24$ (n. 56).

108 SERTORIO, Luigi. La "culpa in concreto nel diritto romano e nel diritto odierno. Torino: Fratelli Bocca, 1914 , p. 40.

109 Sobre a possibilidade de influir na fattispecie o valor diferenciado entre a coisa emprestada e a coisa pessoal do comodatário, v. nota 153 infra.

110 SERTORIO, Luigi. op. cit., p. 40-42. Deve-se questionar se fosse hipótese de "diligentia quam suis" este fragmento, pois se fosse o caso, quando a coisa emprestada ou a coisa própria do comodatário perecessem por força maior, deveria haver claramente ressarcimento e responsabilidade do devedor, embora o fragmento não imponha esta responsabilidade.

111 SERTORIO, Luigi. op. cit., p. 42.
} 
Este posicionamento se consolidaria na "praesumptio iuris et de iure" da L. Vis. (Lex Visigotgorum sive Liber iudiciorum) 5, 5, 2, que estabelecia a obrigação de ressarcir pelo infortúnio das coisas alheias não perecerem junto com as próprias. ${ }^{112}$

Assim, a existência de um substrato objetivo em Ulp. 28 ad ed., D. 13, 6, 5, 4 não tem sido negada, mas aceita, por alguns de forma mais tímida, ${ }^{113}$ e por outros de forma mais ampla, ${ }^{114}$ mesmo em período pós-clássico. ${ }^{115}$

4. 3. Fundamentos doutrinários e utilidade prática: negação, culpa, sistema de princípios e responsabilidade objetiva

Nem todas as legislações prevêem expressamente o princípio de sacrificio da coisa própria, mas para Juilius Ritter Staudinger e Karl Kober, ${ }^{116}$ embora da omissão, é possível a configuração desta hipótese de responsabilidade agravada a partir de uma dedução do $\S 603$ do BGB, sendo que qualquer desmembramento implícito pressupõe que o comodatário deva usar da coisa conforme os ditames da gratuidade e da moderação, ${ }^{117}$

${ }^{112}$ Id. Ibid. O que seria inadimissível, para este último autor, seria a extensão por analogia de uma norma especial agravadora da responsabilidade, devendo ser combatida a doutrina que se embaseia no princípio de ser uma ofensa à boa-fé o uso de mais diligência para as coisas pessoais do que para as alheias.

113 LUZZATTO, Giuseppe Ignazio. Caso fortuito e forza maggiore come limite alla responsabilità contrattuale - La responsabilità per custodia. cit., p. 135-136.

114 SERTORIO, Luigi. op. cit., p. 40-42.

115 Sobre a configuração da fattispecie no direito medeval e moderno v. SANTARELLI, Umberto. op. cit., p. 34-37, segundo o qual os medievais teriam definido a partir da gratia, três espécies de comodato: "gratia commodantis", "gratia utriusque" e "gratia commodatarii", colocando as duas séries ternárias pela culpa (lata, leve, levissima) e pela gratia (commodantis, utriusque e commodatarii) em correlação . Assim, no "comodato gratia commodantis", o comodatário respondia somente por dolo e culpa lata, no "comodato gratia utriusque", por dolo, culpa lata e culpa levis, e, no "comodato gratia commodatarii", o mais recente, a responsabilidade se estendia do dolo até a culpa levíssima. Em toda esta evolução que o comodato passou entre a Idade Média e Moderna, que configura, na realidade, uma Idade Intermédia, delineou-se uma política de direito que pode ser definida de modo claro, porém não-elegante, de "favor commodatarii". Para se presenciar esta evolução basta perceber o ponto inicial desta evolução, representado pela expressão clássica romana "praestare custodiam" e o último ponto, que é a constituição de um sistema plúrimo da culpa graduado conforme a configuração da "gratia". Todo este sistema constituído arduamente e claramente na Idade Intermédia, com base na politica do "favor commodatarii" é extremamente coerente ao exaltar a essência gratuita e, nos limites do acordado, aliviar a situação do comodatário.

Sobre a configuração do comodato no direito canônico, bem como de seu paralelo com o instituto do "precario", v. BUSSI, Emilio. La formazione dei dogmi di diritto privato nel diritto comune - Contratti, successioni, diritti di famiglia. In: Studi di diritto privato italiano e straniero diretti da Mario Rotondi. Padova: CEDAM, 1971, v. 27, p. 57-61 (=n. 85), segundo o qual o direito canônico distinguiu e aprofundou o contrato de "precario" construído pelo direito romano, ampliou o objeto cabível no comodato, e enunciou dois princípios. O primeiro pelo qual o comodante deve esperar o uso da coisa pelo comodatário para pedir sua devolução, e o segundo pelo qual o comodatário respondia pela culpa levíssima, no comodato "gratia sui".

116 KOBER, Karl; STAUDINGER, Julius Ritter. op. cit., p. 644-645 (= § 603).

117 Id. Ibid., p. 644-645 (= §603). 
qualidades que impõe ao uso certas limitações quanto à natureza, ao uso estipulado e ao tempo, porém não quanto ao princípio de sacrifício da coisa própria.

$\mathrm{Na}$ realidade, se por um lado, a hipótese pode ser implicitamente dedutível, por outro lado, ela não poderá ser configurada concretamente, em primeiro lugar, devido à percepção de que o ordenamento jurídico arquitetaria diversamente o oposto, e, em segundo lugar, devido à constatação de que o valor das coisas em risco de serem destruídas é o critério mais importante de ser observado, vale dizer, o critério predominante. ${ }^{118}$

De forma muito semelhante, Franco Carresi ${ }^{119}$ utiliza do critério do valor para realizar um ataque essencialmente econômico, o que acarretará, juridicamente, uma tentativa de diminuição ao máximo da aplicação concreta do princípio de sacrifício da coisa própria, mesmo sendo este explicitamente previsto pelo art. $1.805, \S 1^{\circ}$ do CC italiano.

A falta de fundamento deste princípio residiria no fato da lei gravar o comodatário com o ônus de arcar com um sacrifício bem maior, sem direito a qualquer reembolso ou justa indenização.

Assim, se qualquer ordenamento jurídico previr o reembolso pelas despesas extraordinárias, tornar-se-ia inadmissível o princípio segundo o qual o comodatário fosse responsável pelo perecimento da coisa emprestada nos moldes do princípio de sacrifício da coisa própria. ${ }^{120}$

$\mathrm{O}$ argumento de que se trataria de um agravamento ao parâmetro de comparação da diligência do comodatário não seria suficiente para caracterizar a lógica do princípio, que com toda certeza e coerência deve ser rechaçado em uma concepção sistêmica que preveja o reembolso pelas despesas extraordinárias, o que, na realidade, ocorre, em grande parte dos sistemas. ${ }^{121}$

Não havendo outro caminho, estando as duas disposições presentes, deve-se tender a diminuição da aplicação do princípio de sacrifício da coisa própria, originando uma obrigação excepcional e eventual do comodatário, ${ }^{122}$ uma vez que este não encontra uma efetiva aplicação prática, seja pela constatação de que a coisa pessoal do comodatário seja mais valiosa, seja pela caracterização da força maior ou de grave risco. ${ }^{123}$

\footnotetext{
118 Id. Ibid., p. 645.

119 CARRESI, Franco. Il comodato - Il mutuo. cit., p. 62. A opinião de F. Carresi é acompanhada pela de PERLINGIERI, Pietro. Codice civile annotato con la dottrina e la giurisprudenza: delle obbligazioni. Napoli: Scientifiche Italiane, 1991. v. 4, t. 2, p. 1.364.

120 Assim, a contrario sensu, um ordenamento que não traga disposição sobre o reembolso das despesas extraordinárias pode trazer este princípio com plena coerência.

121 V. arts. 583 e 584 CC/2002.

122 CARRESI, Franco. Comodato (diritto civile). cit., p. 692-696.

123 FRAGALI, Michele. op. cit., p. 216-218, muita confusão é feita por F. Carresi, através da afirmação que com a previsão do direito de reembolso pelas despesas extraordinárias não seria correto impor ao comodatário um dano muito maior representado pelo sacrifício da própria coisa sem lhe dar a devida indenização. A
} 
De forma diversa e embora a communis opinio ${ }^{124}$ assuma a defesa de uma "culpa levis in abstracto" como parâmetro da responsabilidade do comodatário, Robert-Joseph Pothier ${ }^{125}$ e José de Aguiar Dias ${ }^{126}$ defendem que a culpa levíssima, seria a justificativa na hipótese do princípio de sacrifício da coisa própria, uma vez que nestas a culpa é apreciada ao extremo. ${ }^{127}$

Embora não aceite como fundamento este agravamento da diligência ordinária, para Ernesto Brunori ${ }^{128}$ este continua a se estruturar sobre a máxima não há responsabilidade sem culpa. ${ }^{129}$

Assim, a justificativa do princípio de sacrifício da coisa própria somente poderia ser encontrada na própria diligência do "bonus paterfamilias", que sacrificaria a própria coisa em prol da coisa emprestada, ${ }^{130}$ sendo que o único limite de validade importante ao princípio de sacrifício da coisa própria é a efetiva responsabilidade pela escolha. ${ }^{131}$

falha no raciocínio está em igualar circunstâncias que nada apresentem em comum, e que, portanto, devem ser reguladas de formas diferentes, o que, de fato, não gera qualquer contradição. O comodatário detém o direito de reembolso por estar autorizado a substituir o comodante em sua obrigação de manter a coisa emprestada em estado que possa servir ao uso, e não para evitar a diminuição patrimonial que converteria em uma vantagem ao comodante. Por substituir o comodante em sua obrigação, lhe é devida um ressarcimento. Ao contrário, o princípio de sacrificio da coisa própria refere-se a uma obrigação pessoal e exclusiva do comodatário, e, logo, o sacrifício da coisa representa o adimplemento de sua obrigação prevista pela lei como especificação de seu dever de diligência na conservação da coisa emprestada. Assim, nenhuma indenização é permitida na princípio de sacrificio da coisa própria, para que não ocorra a conversão de uma obrigação do comodatário ao comodante.

${ }^{124}$ Cf. GONÇALVES, Luiz da Cunha. Tratado de direito civil. cit., p. 309, TAMBURRINO, Giuseppe. op. cit., p. 994-1.006 entre outros. Mais coerentemente CARRESI, Franco. Il comodato - Il mutuo. cit., p. 59-61.

${ }^{125}$ BRUNORI, Ernesto. op. cit., p. 25.

126 DIAS, José de Aguiar. op. cit., p. 24-26.

127 BEVILAQUA, Clóvis. op. cit., p. 437.

${ }^{128}$ BRUNORI, Ernesto. op. cit., p. 25.

${ }^{129}$ Id. Ibid., p. 25.

${ }^{130}$ Embora afirme que se trataria de uma conduta esperada de um bonus paterfamilias, BRUNORI, Ernesto. op. cit., p. 25, afirma, erroneamente, que o comodatário será responsabilizado por ter agido com culpa ou dolo, pois ao comodatário será imposta a responsabilidade pelo caso fortuito, independentemente se depois deste agiu culposamente ou não.

131 Segundo CARRESI, Franco. Il comodato - Il mutuo. cit., p. 63, a defesa realizada por Ernesto Brunori, um dos maiores defensores do princípio, que estabelecia o argumento de que existe, na realidade, um aumento na diligência a ser respeitada pelo comodatário, caracterizando a responsabilidade agravada, apresenta um erro em sua sustentação. De forma semelhante, segundo BAUDRY-LACANTINERIE, Gabriel; WAHL, Albert. op. cit., p. 364-366 (= n. 640-643), para que o princípio de sacrificio da coisa própria se concretize, existe a necessidade de uma violação prévia dos limites contratuais, ou seja, o comodatário deve ter, antes da ocorrência do caso fortuito, incidido, pelo menos, em culpa. A hipótese se baseia justamente na concepção histórico-dogmática de que o comodato não foi criado para que o comodatário poupasse suas coisas para utilizar as emprestadas, bastando esta atitude para incorrer em culpa. Diferentemente do principio de sacrifício da coisa própria, o ocultamento configurar-se-ia com a dissimulação da existência de uma coisa pessoal do comodatário no momento da formação do contrato. Sobre este v. nota 167 infra. 
Com uma postura menos intransigente quanto ao requisito moral, ${ }^{132}$ para Luigi Borsari o comodatário deveria, como regra, apenas usar da coisa emprestada por bondade e complacência de terceiro, quando houvesse necessidade, devendo sempre preferir o uso das próprias coisas. ${ }^{133}$

Assim, o princípio de sacrificio da coisa própria basear-se-ia na máxima de que "o comodatário deve sempre usar primeiro suas coisas do que as emprestadas", onde a necessidade determinaria sua responsabilidade e seu comportamento honesto e de boa-fé.

Embora Luigi Borsari ${ }^{134}$ demonstre que se trata de uma norma da mais alta moralidade e responsabilidade, uma vez que a escolha a ser realizada em meio ao caso fortuito atenta contra a própria natureza das coisas, os limites concretos merecem atenção, já que o comodatário deve proteger a coisa emprestada como se fosse a mais preciosa existente, sendo não se deve impor ao comodatário o sacrifício de uma grande fortuna pessoal em troca de um objeto que não vale nada.

Assim, embora alguma ofensa venha a ser gerada para o comodante, este poderá ser rapidamente ressarcido, o que atinge o mais importante objetivo do princípio, isto é, de que nenhum dano seja gerado para este, ${ }^{135}$ sendo que o fundamento moralista acaba por ser ponderado por argumentos jurídicos e econômicos.

Como sustenta Michel Fragali, ${ }^{136}$ todos estes posicionamentos poderiam caracterizar um fundamento correto no século XIX, porém não atingeriam o mérito da situação, uma vez que são eminentemente morais, e não-jurídicos. ${ }^{137}$

Trata-se da defesa de que a escolha pela coisa do comodante deve ser feita, pois este proporcionou uma vantagem gratuita ao comodatário, merecendo o devido

\footnotetext{
${ }_{132}$ O que permitiria afirmar que enquanto E. Brunori, Dei contratti specialli cit. (nota 1. 1. supra), p. 25, e BAUDRY-LACANTINERIE, Gabriel; WAHL, Albert. op. cit., p. 364-366 (= n. 640-643), assumem a defesa de uma moralidade plena, BORSARI, Luigi. op. cit., p. 110-111, inspira-se em uma moralidade ponderada em aspectos jurídicos e econômicos.

133 BORSARI, Luigi. op. cit., p. 110-111 Este dever especial do comodatário decorreria do princípio de que o uso da coisa deve ocorrer segundo a previsão contratual, sendo que o comodante na formação do contrato pressupõe que ao emprestar a coisa está sanando uma necessidade que o comodatário por meios próprios não pode suprir. A contrario sensu, se o comodatário não usar da coisa para sanar uma necessidade especial, incorrerá em culpa, por utilizar ilegitimadamente desta.

${ }_{134}$ BORSARI, Luigi. op. cit., p. 110-111.

135 BORSARI, Luigi. op. cit., p. 108: "È il precetto legal della legge; ma in ultima analisi è una questione di responsabilità e d'indennità".

${ }_{136}$ FRAGALI, Michele. op. cit., p. 216-218.

137 Id. Ibid., p. 216-218; BAUDRY-LACANTINERIE, Gabriel; WAHL, Albert. op. cit., p. 364-366 (= n. 640643), que sustentam que a culpa levissima é um padrão desatualizado da responsabilidade do comodatário.
} 
reconhecimento, e ao colocar seus interesses em primeiro plano, mesmo se mais valiosos, o comodatário viola as leis da delicadeza e da educação. ${ }^{138}$

Uma outra fundamentação buscou a construção de um sistema de princípios, percebendo que histórica e dogmaticamente três concepções doutrinárias assumiram o compromisso de buscar o fundamento jurídico do princípio de sacrifício da coisa própria. $^{139}$

A primeira justificativa ao princípio apoia-se no respeito, e também no próprio reconhecimento, que o comodatário deve ao comodante. ${ }^{140}$

Uma segunda tentativa de justificar o princípio juridicamente está na criação de uma responsabilidade específica e própria do comodatário derivada da própria obrigação de conservação, sendo que da própria norma jurídica emanaria a responsabilidade agravada do comodatário, da disposição jurídica decorrência lógica seria uma responsabilidade própria do comodatário. ${ }^{141}$

${ }_{138}$ BAUDRY-LACANTINERIE, Gabriel; WAHL, Albert. op. cit., p. 365. Também na defesa do fundamento da fattispecie na culpa, entre outros, CHIRONI, Giampietro. La colpa nel diritto civile odierno - Colpa contrattuale. Torino: Fratelli Bocca, 1884,p. 54-56 (n. 58), LAURENT, François. op. cit., p. 482-484 (= n. 474), MIRABELLI, Giuseppe. op. cit., p. 29-33, 37-39. TROPLONG, Raymond-Théodore. op. cit., p. 96101 (= n. 113-118), narra o posicionamento das regras da razão natural quando ela impõe ao comodatário o sacrifício de um bem pessoal. Este posicionamento baseaia-se em um argumento que, quando o cuidado que se tem com assuntos ou coisas pessoais está em concorrência com o cuidado com coisas ou assuntos alheios, de forma que não se pode se dedicar à ambos, é absolutamente natural que se importe com o primeiro, vale dizer, sendo todas as coisas iguais, deve-se pensar no que é pessoal sem que se faça nada pelo que é alheio. Por esta linha de pensamento, a responsabilidade imposta ao comodatário, em meio à uma força maior que não permite salvar as coisas alheias sem sacrificar as própria, está totalmente desconforme com o direito natural, sendo simplesmente o princípio de sacrificio da coisa própria explicado por uma arbitrariedade dos juristas romanos. Esta linha de pensamento estaria completamente errada, pois substitui o reconhecimento pelo egoísmo, em uma relação onde o primeiro e não o segundo deveria imperar, sendo apenas admissível em casos ordinários, onde não se deve realmente impor à alguém a obrigação de se esquecer de assuntos do próprio interesse, para que passe a cuidar de interesses alheios em igual perigo. Nem a moral, muito menos a religião, iriam impor um sacrifício tão penoso para a natureza humana. Logo, estando as duas coisas ameaçadas, e não podendo o comodatário salvar ambas, não deve ele sacrificar a emprestada. Trata-se de um sentimento invencível de justiça que demonstra que é justamente esta que deve ser salva, uma vez que ela só corre o perigo por estar nas mãos do comodatário. Frente a coisa emprestada, o comodatário figura como representante do comodante, e deve ser por isto a mais preciosa do patrimônio do comodatário. O que se tem certeza é que o princípio de sacrificio da coisa própria configura uma situação excepcional e particular, independentemente de qual seja seu fundamento.

139 FRAGALI, Michele. op. cit., p. 216-218.

140 É a concepção de DE AGUIAR DIAS, José. op. cit., p. 24-26., BRUNORI, Ernesto. op. cit., p. 25 e BORSARI, Luigi. op. cit., p. 110-111.

141 Esta corrente doutrinária se assemelha à CARRESI, Franco. Il comodato - Il mutuo. cit., p. 62 e KOBER, Karl; STAUDINGER, Julius Ritter. op. cit., p. 645. 
Mais acertadamente, uma terceira tentativa, reconhece o princípio de sacrifício da coisa própria entre aqueles que exoneram a responsabilidade do devedor fundando-se em um outro princípio, ou seja, no estado de necessidade. ${ }^{142}$

Recentemente tem-se defendido que o comodatário responde, como já detemonstrava Franco Pastori, ${ }^{143}$ pela custódia, figura esta da responsabilidade objetiva, que encontra o fundamento da responsabilidade agravada na "utilitas contrahentium", a qual era obtida exclusivamente pelo comodatário, que usa da coisa gratuitamente, conforme Gai. 3, 206. ${ }^{144}$

Primeiramente, deve-se atentar para o fato que a chamada "responsabilidade por custódia", refere-se a uma "custódia (denominada) técnica", distinta ontologicamente da "custódia atécnica", que designa apenas a mera atividade de custodiar a coisa e a sua obrigação relativa. ${ }^{145}$

A "responsabilidade por custódia" é figura primitiva da responsabilidade do comodatário, que se aplica no contexto da fórmula in factum, onde o juiz não

${ }_{142}$ Não é possível que se deseje o adimplemento de uma obrigação por estado de necessidade sem que este gere conseqüências jurídicas para - na realidade - o inadimplente, pois, primeiramente, transgrediu-se a obrigação genérica presente no sistema denominado "neminem laedere". Assim, conforme FRAGALI, Michele. op. cit., p. 216-218, o correto entendimento do " princípio de sacrifício da coisa própria " deve ser feito frente ao princípio do estado de necessidade, que obriga ao autor do dano à ressarci-lo.

143 PASTORI, Franco. Comodato (Diritto Romano). cit., p. 688-692.

144 Para PASTORI, Franco. Comodato (Diritto Romano). cit., p. 688-692, por outro lado, o comodatário é legitimado da "actio furti" frente ao ladrão e tem sua preferência frente ao "dominus" da coisa emprestada, ao qual compete contra o ladrão somente à “condictio ex causa furtiva”. Uma vez que é responsável por custódia, tendo a res commodata sido furtada, o proprietário da coisa emprestada pode agir contra o comodatário mediante a "actio commodati" para obter uma indenização. Assim, o sujeito mais interessado na coisa não é o dominus, mas sim, pelo contrário, o comodatário, sobre o qual gravam as conseqüências danosas do furto. Este regime se une a norma enunciada em Gai. 3, 203, enunciando que a "actio furti" não compete de forma geral ao dominus da coisa roubada, mas aquele "cuius interest rem salvam esse", norma inteiramente aplicável ao comodatário, ao "fullo", ao "sarcinator" - os quais respondem igualmente por custódia - e ao credor pignoratício, que se interessa na conservação da coisa, uma vez que esta é a garantia de seu crédito. Esta idéia também se apresenta nas Inst. 4, 1, 16.

145 PASTORI, Franco. Comodato (diritto romano). cit., p. 688-692. LUZZATTO, Giuseppe Ignazio. Custodia (Diritto Romano). cit., p. 93-94, sustenta que de uma forma pouco técnica, o termo "custódia" indica uma atividade normal de custodiar, encontrando até emprego no âmbito da responsabilidade contratual, como, por exemplo, a guarda da coisa confiada ao "familiae emptor", ao "missus in possessionem" entre outros. Entretanto, no campo da responsabilidade contratual, o termo assume uma fisionomia técnica muito precisa, indicando um critério exato de responsabilidade objetiva. Assim, o critério da "custódia" indica a porção de risco adossada ao comodatário no âmbito de certas relações contratuais, independentemente de seu conteúdo ou responsabilidade subjetiva. Esta custódia técnica torna-se mais complexa na obra dos compiladores, que, em diversos textos, desnatura esta visão clássica da custódia, transformando-a em uma "diligentia in custodiendo", estando sujeita as diversas incertezas decorrentes da valorização desta obra em matéria contratual. Originariamente duas correntes começaram a se configurar sobre esta transformação do termo "custodia" nesta obra monumental. A pandectícia alemã tendeu a atribuir, no período clássico, à custódia o significado de uma responsabilidade objetiva, e, no Direito justinianeu, a passagem para uma responsabilidade subjetiva, enquanto a doutrina italiana generalizou a custódia para todas as relações obrigacionais no Direito justinianeu. 
detém qualquer poder de examinar o comportamento do comodatário, condicionando a condenação ao "non reddere", a obrigação principal do comodatário, que é, justamente a da devolução da coisa emprestada.

A "bona fides", com o surgimento da fórmula in ius, importaria em uma aprofundada consideração por parte do juiz do comportamento pessoal do comodatário, comparando este com a conduta de uma pessoa correta e criando-se a antítese da própria responsabilidade objetiva, já que ao se valoriza o "factum debbitoris" valoriza-se a concepção de "diligentia", que viria a se consubstanciar em uma figura bem definida tecnicamente, esboçada no conceito dogmático e técnico da "responsabilidade por diligentia", paralela a "responsabilidade por culpa".

No Direito clássico se verificou uma linha de continuidade, por um lado, entre a fórmula in factum do comodato e a obrigação de restituição e a "responsabilidade por custódia" e, por outro lado, entre a fórmula da boa-fé e uma responsabilidade de natureza subjetiva. ${ }^{146}$

A aproximação da custódia da diligência, no período pós-clássico levaria a fusão destas duas figuras em Ulp. 28 ad ed., D. 44, 7, 1, 4 e Ulp. 28 ad ed., D. 13, 6, 18 pr., respectivamente, nos conceitos de "diligentia exactissima in custodiendo" e/ou "diligentia diligenti custodiendo". ${ }^{147}$

Luigi Sertorio ${ }^{148}$ demonstra que mesmo em período pós-clássico o comodatário permanece em algumas circunstâncias respondendo objetivamente, como ocorreria em Ulp. 28 ad ed., D. 13. 6. 5. 4, por embasamento na custódia clássica, o que, da mesma forma, larga parte dos autores modernos continua a entender como fundamento do princípio de sacrificio da coisa própria.

146 PASTORI, Franco. Comodato (diritto romano). cit., p. 688-692. A mesma situação se encontra no âmbito na "actio commodati contraria", a qual, pela fórmula in factum estabelece a obrigação incondicionada do comodante de reembolsar o comodatário pelas despesas necessárias, enquanto pela fórmula in ius, baseada na bona fides, estabelece-se o resarcimento do dano para o comodatário quando este se verificou por dolo do comodante. Mesmo que abstractamente pode-se explicar o porquê se continuou a se aplicar aos casos concretos, como a jurisprudência demonstra, a fórmula in factum, ao invés de retirá-la imediatamente, uma vez que o comodato foi tutelado por uma fórmula in ius, o que determinaou a colocação do comodato na rubrica edital de "rebus creditis". A fórmula in factum continuou a servir a uma função vital, uma vez que permite, ao contrário da fórmula de boa-fé, na falta de restituição da coisa emprestada, a aplicação sobre o comodatário da mais grava responsabilidade, vale dizer, da custódia. Esta também seria a peculiar diferença entre o comodato e o depósito.

147 Através da expressão "diligentia exactissima in custodiendo" haveria o enquadramento da responsabilidade do comodatário no âmbito da "diligentia", mas de uma diligência extremamente rigorosa, cuja prova era muito difícil de ser realizada. Tratava-se, na prática, de uma responsabilidade não diferente da "custodia", pois, o que, na realidade, houve, foi a conservação do regime clássico da responsabilidade do comodatário - "responsabilidade por custódia" - com a mudança do pressuposto teórico.

148 SERTORIO, Luigi. op. cit., p. 40-42. 
Assim, G. A. Ferrario, ${ }^{149}$ entende que o princípio de sacrificio da coisa própria se sustente objetivamente através de um juízo de eqüidade e, da mesma forma, Roberto De Ruggiero e Fulvio Maroi, ${ }^{150}$ entendem que na fattispecie o comodatário responde independentemente de culpa, e como exceção a obrigação de custodiar e conservar a coisa emprestada, e, Agostinho Alvim, ${ }^{151}$ no Direito brasileiro, dentre as hipóteses baseadas no risco, insere a do comodatário, pois responde este por obrigação de resultado, e não de meio.

Da própria observação realizada por Michel Fragali, ${ }^{152}$ ao se preferir a expressão "per una causa non imputabile al debitore" ao tratar da impossibilidade da prestação, imputa-se um evento objetivamente ao comodatário. ${ }^{153}$

${ }_{149}$ FERRARIO, G. A. op. cit., p. 385-405. V. cap. IV. 2.

${ }^{150}$ DE RUGGIERO, Roberto; MAROI, Fulvio. op. cit., p. 359 (= § 163). No mesmo sentido, MESSINEO, Francisco. Manuale di diritto civile e comerciale - Codici e norme complementare - Singoli rapporti obbligatori - Diritti delle successioni per causa di morte - Elementi di diritto privato internazionale. 7 ed. Milano: Giuffrè, 1957, v. 3, p. 3-594 (= n. 139-169). pp. 193-194 (= § 158).

151 ALVIM, Agostinho. op. cit., p. 196-199, 287 (=n. 149 e 192).

152 FRAGALI, Michele. op. cit., p. 211-213.

153 Uma hipótese pela qual se demonstra inegavelmente que se trata de um fundamento objetivo de responsabilidade está no caso de existir uma diferença de valor entre os objetos no princípio de sacrificio da coisa própria, especialmente quando a coisa pessoal do comodatário detém um valor superior à emprestada. Embora FRAGALI, Michele. op. cit., p. 216-218, sustente que em nada incorre na vigência do princípio, se a coisa própria do comodatário for de valor maior do que a coisa emprestada, pois em nada interfere na distinção de estado de necessidade e impossibilidade de adimplemento e da afirmação de BAUDRY-LACANTINERIE, Gabriel; WAHL, Albert. op. cit., p. 364-366 (= n. 640-643) que em nada importa a imensidão do sacrificio do comodatário, certas circunstâncias especiais merecem uma atenção. Esta hipótese particular do princípio de sacrificio da coisa própria, foi proposta - e debatida - por POTHIER, Robert-Joseph. op. cit., p. 2324 (n. 56). Quando as coisas que tinham sido emprestadas detinham um valor maior que as próprias do comodatário, as quais detinham menor valor do que àquelas, pois o cuidado que se deve ter com as coisas emprestadas deve ser no mínimo aquele que se tem com as coisas próprias. Dentro deste contexto, se as coisas emprestadas pertencessem não ao comodante, mas sim ao comodatário, este iria preferir salvar estas, por serem mais valiosas, do que as outras menos preciosas. Deixa, assim, de ter o cuidado que deveria ter, deixando-as perecer para salvar aquelas que na realidade possuía. Vice-versa, se as coisas que pertenciam ao comodatário detinham o maior valor, ou seja, eam mais preciosas que aquelas emprestadas, e que ele deixou perecer, não podendo salvar ambas, continua este a ser responsável pela perda das coisas alheias. Deve-se sustentar que mesmo neste caso, no entendimento de Robert-Joseph Pothier, será o comodatário responsável pela perda das coisas alheias. Por outro lado, é verdade, neste caso, que não se pode censurá-lo por não ter tido o mesmo cuidado que apresenta com as coisas pessoas frente as emprestadas, uma vez que, se estas coisas emprestadas the tivessem pertencido, ele as deixaria perecer da mesma forma, pois salvaria as mais preciosas. Assim, no caso das coisas pessoais do comodatário valerem mais, não se pode dizer que este cometeu uma infidelidade para com o comodante. A solução desta hipótese esta na percepção que a obrigação do comodatário não nasce da fidelidade ou não dele com as coisas emprestadas em igual modo que as próprias, vale dizer, a obrigação não se configura mais por se ter o mesmo cuidado que se tem com as coisas próprias para com as emprestadas, mas, pelo contrário, o comodatário é obrigado a ter todo o cuidado possível, "tenetur adhibere exactissimam diligentiam". O comodatário torna-se responsável, por força do próprio contrato de comodato, pelo perecimento das coisas que lhes são entregues, exceto a hipótese de força maior. Contrário ao fundamento conferido por Robert-Joseph Pothier ao próprio princípio de sacrificio da coisa própria, FERRARIO, G. A. op. cit., p. 385-405, demonstra que a circunstância é extremamente lógica. Uma vez que o comodatário deve ressarcir o comodante do valor da coisa perdida e, no caso concreto, o 


\section{4. Requisitos para a configuração da responsabilidade agravada}

Além do debate acerca do fundamento e pertinência do princípio de sacrificio da coisa própria, tão, ou mesmo mais, importante, é a análise dos seus limites de validade, e, assim, conseqüentemente, de seus requisitos, já que é por estas autênticas condições que este se configura e não com a mera prova que demonstre a possibilidade do comodatário salvar a coisa emprestada. ${ }^{154}$

A partir do momento em que se aceita a presença de duas vertentes do mesmo princípio, impõem-se requisitos genéricos, vale dizer, em comum, e requisitos especificos, particulares de cada uma.

Dentre os genéricos, o primeiro requisito é a necessidade que o comodatário apresente, em seu patrimônio, uma coisa para sacrificar, a fim de que a coisa emprestada seja salva do caso fortuito. ${ }^{155}$

comodatário sempre deixará perecer a coisa de menor valor independentemente de qual for, ou seja, no caso do objeto do comodato valer menos, deixará o comodatário que a coisa alheia perecer, já que a sua coisa detém um valor maior. O objetivo da lei é único, isto é, o comodatário deve ressarcir o comodante pelo perecimento da coisa emprestada, não se querendo exigir qualquer sentimentalismo e delicadeza do comodatário a ponto que este perca um bem de valor desmesurável em troca da salvação de um objeto minúsculo, e até vulgar, do comodante. BORSARI, Luigi. op. cit., p. 110-111, afirma que implicitamente a coisa emprestada deve ser considerada como a mais valiosa existente para o comodatário, mas o bom senso deve operar na interpretação da lei, pois não se trata de um desejo legal que se troque toda a fortuna pessoal do comodatário por parcos livros. Se por um lado este é o momento ideal para se analisar o cuidado devotado pelo comodatário à coisa emprestada, uma vez que a pressão de perder a própria vida e seus pertences mais valiosos é a mais forte existente, nenhuma lei - e nenhuma sociedade -, por outro lado, desejaria impor ao comodatário um sacrifício de tal ordem. A solução, diante a omissão legal, é a adotada por CARRESI, Franco. Il comodato - Il mutuo. cit., p. 62, devendo ser casuística. Se no caso concreto percebe-se que a coisa do comodatário detém um valor maior ou notavelmente superior aquela emprestada, este, obviamente deixará esta perecer, mesmo que tenha que ressarcir ao comodante, pois, uma vez que terá que arcar com algum perecimento, preferirá sua, por ter maior valor. Assim, conforme BORSARI, Luigi. op. cit., p. 110111, o objetivo final do " princípio de sacrificio da coisa própria » é impedir que o comodante venha a sofrer qualquer prejuízo decorrente de um comportamento do comodatário. Uma vez escolhida a coisa pessoal, bastará ao comodatário ressarcir o comodante de seu prejuízo, pois sua responsabilidade pelo perecimento da coisa emprestada ainda será plena, sendo que se percebe, por esta hipótese especial do princípio de sacrificio da coisa própria, que, apresentando-se o dano e o nexo causal, seria suficiente para caracterizar a responsabilidade agravada objetiva do comodatário.

154 FRAGALI, Michele. op. cit., p. 216-218, que sustenta a limitação do princípio, o que garante ao comodatário a exoneração de sua responsabilidade se suas condições de validade forem violadas.

155 BAUDRY-LACANTINERIE, Gabriel; WAHL, Albert. op. cit., p. 364-366, reconhecem a flexibilidade da responsabilidade do comodatário se este utilizar a coisa pessoal e a emprestada de forma alternada, ou se o comodante expressamente conhecia e aceitou o não-uso da coisa pessoal do comodatário. Assim, para FERRARIO, G. A. op. cit., p. 385-405, trata-se de uma questão de sutileza para a ocorrência do " princípio de sacrificio da coisa própria », pois este pressupõe para sua caracterização de uma coisa pessoal do comodatário, vale dizer, na propriedade e na disponibilidade do comodatário e sobre a influência do mesmo evento fortuito. Sustentar o contrário significa dizer que mesmo o comodatário não tendo a coisa em sua propriedade, deve procurar-la, e caso se omita de tal ato, estaria incorrendo em uma responsabilidade não prevista expressamente pela lei. Assim, "cosa propria del comodatario", prevista no art. $1.805, \S 1^{\circ}$ do 
Entretanto, além deste, exige-se que se trate realmente de um caso fortuito, pois, caso seja uma força maior deve ser a responsabilidade do comodatário afastada, ${ }^{156}$ pois nenhuma escolha pode ser realizada nas circunstâncias da força maior. ${ }^{157}$

Também se requer o requisito negativo da não caracterização de um grave risco para o comodatário, isto é, um risco maior do que aquele sob o qual se submeteria para salvar sua coisa. ${ }^{158}$

Por fim, genericamente, exige-se a concretização de uma escolha, para que este se encontre em estado de responsabilidade agravada. ${ }^{159}$

Luigi Borsari exige, erroneamente, uma "facoltà della scelta", ${ }^{160}$ um poder abstrato de escolha do comodatário, o que demonstraria uma ausência de diferença entre as duas vertentes do princípio de sacrifício da coisa própria ${ }^{161}$ o que não é de qualquer forma admissível, pois o que se exige é a "effetiva possibilità di scelta", pois é no caso concreto que se permite a existência de uma autêntica possibilidade de escolha. ${ }^{162}$

Além de todos estes requisitos genéricos, também se impõe um requisito especifico para a caracterização uma ou outra das vertentes do princípio de sacrifício da coisa própria.

Embora a existência deste princípio dependa exclusivamente da presença do risco, ou seja, do momento sob o qual a coisa emprestada apresentar-se-á sob este, ${ }^{163}$ a forma e as condições como este se materializará, configurarão ora uma, ora outra vertente.

Ernesto Brunori ${ }^{164}$ adequadamente compreende que para a caracterização da primeira vertente depende da ocorrência de um perigo apenas para a coisa emprestada, enquanto que na segunda vertente exige-se um risco de perecimento da coisa emprestada e da coisa pessoal do comodatário por decorrência do mesmo caso fortuito. ${ }^{165}$

CC italiano, se refere aquela coisa que já deve estar sob a disponibilidade do comodatário no momento da ocorrência do evento, vale dizer, uma coisa já presente no patrimônio do comodatário.

156 Sobre a força maior, v. item. 4. 5.

157 BORSARI, Luigi. op. cit., p. 110-111.

158 CARRESI, Franco. Il comodato - Il mutuo. cit., p. 61-63 (= § 40).

159 BAUDRY-LACANTINERIE, Gabriel; WAHL, Albert. op. cit., p. 364-366 (=n. 640-643).

160 BORSARI, Luigi. op. cit., p. 110-111.

161 BRUNORI, Ernesto. op. cit., p. 25, afirma que a diferença entre uma e outra vertente não se encontra na escolha, mas no modo em que o risco se concretiza, para que injustiças sejam evitadas com o devedor.

162 Id. Ibid., p. 25. No mesmo sentido, DE CARVALHO SANTOS, João Manuel. op. cit., p. 421-423

163 A rigor, o risco em si não pode ser caracterizado como um requisito do princípio do sacrificio da coisa própria, pois se refere ao próprio conceito de responsabilidade agravada.

164 BRUNORI, Ernesto. op. cit., p. 24-25.

165 BAUDRY-LACANTINERIE, Gabriel; WAHL, Albert. op. cit., p. 364-366 (= n. 640-643). 
Isto implica, a contrario sensu, que se a coisa emprestada e a coisa pessoal do comodatário estiverem em perigo de perecer por casos fortuitos diversos, não ocorrerá a caracterização da segunda vertente do princípio de sacrifício da coisa própria.

Este último requisito especifico da segunda vertente tem sido materializado na doutrina, ${ }^{166}$ pela necessidade de "identidade espaço-temporal" entre ambas as coisas, para que ocorra a caracterização da fattispecie, pois se as coisas estiverem em situação espacial e/ou temporal diversa e não compatível, outra hipótese que não o princípio de sacrifício da coisa própria seria caracterizada.

Por fim, quanto ao âmbito de sua validade, existe quem defenda o caráter dispositivo da matéria, considerando válida a cláusula na qual o comodante consente em o comodatário não deva substituir por coisa própria à coisa emprestada ameaçada do fortuito, permanecendo a encargo do comodante o risco. ${ }^{167}$

${ }_{166}$ BARBIERI, Ezio Maria; NAPOLETANO; Vicenzo; NOVITÀ, Mario. op. cit., p. 389-390. Assim, PONTES DE MIRANDA, Francisco Cavalcanti. Tratado de Direito Privado - Parte Especial - Direito das Obrigações - Contrato de Seguro (continuação) - Seguro de vida - Seguro de acidentes pessoais - Seguro de responsabilidade - Seguro de crédito - Seguro de riscos especiais e de universalidade - Seguros mútuos Resseguro - Contrato de Comodato - Contrato de Doação - Contrato de Hospedagem. 2 ed. Rio de Janeiro: Borsoi, 1964, v. 46, p. 172, criticando a redação do art. 1.253 CC/1916 revog. - atual art. 583 CC/2002 -, diz que se utilizou erroneamente a expressão "abandonando" que deve ser interpretada como "no mesmo momento".

${ }^{167}$ FRAGALI, Michele. op. cit., p. 216-218. A doutrina tem confundido sistematicamente a fattispecie sob análise e a hipótese do ocultamento. Embora o " ocultamento » venha sendo considerado por parte da doutrina como derivado da própria redação do " princípio do sacrificio da coisa própria », tratam-se na realidade de hipóteses diversas que não se confundem. Para, LA FARINA, Cesare. op. cit., p. 308-313, o " princípio do sacrificio da coisa própria » deve-se equiparar plenamente a hipótese de " ocultamento », não configurando este uma nova hipótese de responsabilidade agravada do comodatário, mas apenas um desmembramento de uma hipótese mais ampla. Por este entendimento, o « ocultamento » deriva exatamente da descrição do princípio previsto no art. $1.805, \S 1^{\circ}$ do CCI italiano. $\mathrm{O}$ « ocultamento » refere-se a idéia de manter uma coisa própria em sigilo enquanto se usa a alheia, mas, para sua correta caracterização, há a necessidade de que o comodatário preveja que possa vir a acontecer um caso fortuito no futuro e, antevendo a ocorrência deste evento, expõe a coisa emprestada, mantendo em seguro a própria. Da mesma forma, o « ocultamento » se configura quando o comodatário pede e obtém uma determinada coisa alheia, sendo que este esconde a existência de uma coisa própria, a qual serviria para o mesmo uso da emprestada, ou mesmo nega ao comodante a informação sobre a existência desta. Entretanto, como sustenta BORSARI, Luigi. op. cit., p. 110-111 (= §§ 3965), existe entre os deveres do comodatário o de não usar da coisa emprestada pela complacência ou bondade de terceiro, se não há necessidade, devendo sempre que possível preferir o uso das coisas próprias. Este dever especial do comodatário decorre do princípio de que o uso da coisa deve ocorrer segundo a previsão contratual, sendo que o comodante na formação do contrato pressupõe que ao emprestar a coisa está sanando uma necessidade que o comodatário por meios próprios não pode suprir. A violação deste objetivo de sanar a necessidade pessoal, leva o comodatário à incorrer em culpa, uma vez que todo o contrato de comodato se baseia na suposição da necessidade do comodatário. Não utilizando da coisa emprestada conforme sua necessidade, o comodatário estará fazendo um uso ilegítimo desta. É, assim, está máxima de que o comodatário deve sempre usar primeiro suas coisas do em as emprestadas, uma vez que este deseja que o comodatário tenha cuidado no uso da coisa, querendo deter qualquer prejuízo que esta pode vir a sofrer, tornando-a não somente verdadeira, como absoluta. Assim, responsabilidade do comodatário será erigida conforme sua necessidade de usar a coisa para um determinado fim, sendo que esta necessidade não precisa ser absoluta, podendo apenas se referir a comodidade de um amigo. Se o comodato é apenas realizado como 


\title{
4. 5. Análise da fattispecie no Direito moderno: o art. 583 CC/2002
}

\author{
Art. 583 CC/2002. \\ Se, correndo risco o objeto do comodato juntamente \\ com os outros objetos do comodatário, antepuser este $[o$ \\ comodatário] a salvação dos seus [objetos] abandonando o \\ [objeto] do comandante, responderá [o comodatário] pelo \\ dano ocorrido, ainda que se possa atribuir [o dano] a caso \\ fortuito, ou força maior. ${ }^{168}$
}

\section{A doutrina brasileira parece divergir da estrangeira quanto a expressão “ $\ldots a$ caso fortuito, ou força maior". \\ Literalmente, Clóvis Bevilaqua ${ }^{169}$ sustenta que o comodatário será responsável se a coisa perecer, nestas circunstâncias especiais, pelo caso fortuito, e mesmo pela força maior, embora a opinio communis sustente o oposto.}

um conforto ou uma ajuda a um amigo que não detém meios próprios para atingir o desejado, é certamente errado este amigo deixar seus animais de tiro e carga em repouso, enquanto se serve dos emprestados. Da mesma forma, FRAGALI, Michele. op. cit., p. 228-229, afirma ser óbvio que comodatário responderá pelo perecimento da coisa emprestada se obteve a entrega desta ocultando a posse de uma outra coisa idônea para o mesmo uso da primeira. Entretanto, diferente de Cesare La Farina, Michele Fragali demonstra que « ocultamento " não se trata de uma responsabilidade fundada no art. $1.805, \S 1^{\circ}$ do CC italiano, vale dizer, de uma responsabilidade fundada sobre a não exposição do risco da coisa própria, uma vez que a coisa própria nem sequer foi exposta ao risco. Trata-se, na realidade, de um responsabilidade derivada de uma omissão voluntária realizada pelo comodatário na época da formação do contrato. Assim, a diferença entre o ocultamento e o princípio do sacrificio da coisa própria, embora sejam ambos construídos, de uma forma ou de outra, sobre o mesmo dispositivo legal, se consolida no fundamento de ambas as hipóteses. A sustentação, de PERRIS, Corrado. op. cit., p. 403-408, que o ocultamento funda-se-se no dolo por parte do comodatário ou em sua dissimulação feita ao comodante de não possuir uma coisa pessoal apta ao mesmo fim da coisa emprestada, ao mesmo uso, induzindo, por este motivo e esta razão a formação do empréstimo, o qual de outra forma talvez não fosse constituído, demonstra uma diferença vital. A dedução do ocultamento do mesmo dispositivo legal que enuncia o princípio do sacrifício da coisa própria só seria possível em razão da presença de um risco à coisa emprestada, em ambas as hipóteses. Entretanto, o ocultamento traz um elemento a mais residente na percepção que a vontade do comodante está viciada, e, logo, a obrigação assumida seria eivada pela nulidade, com base na regra geral prevista no art. 1.110 do CC italiano, de 1865, revog., o que configura uma hipótese de responsabilidade agravada subjetiva, e não objetiva como o princípio do sacrificio da coisa própria. Assim, PONTES DE MIRANDA, Francisco Cavalcanti. Tratado de direito privado: parte especial - direito das obrigações - auto-regramento da vontade e lei - alteração das relações jurídicas obrigacionais - tranferência de créditos - assunção de dívida alheia - transferência da posição subjetiva nos negócios jurídicos. 2. ed. Rio de Janeiro: Borsoi, 1958, t. 23, p. 77-102, se o evento é previsível e não foram atendidas as medidas para evitá-lo, não se deve considerar nem a formação doe "caso fortuito ou de força maior", pois o comodatário terá incidido no dolo, nem podendo se cogitar em uma responsabilidade agravada objetiva, como ocorre no princípio de sacrificio da coisa própria. O ocultamento configura-se como uma das formas de extinção do contrato de comodato por dolo do comodatário.

168 Redação idêntica ao art. $1.253 \mathrm{CC} / 1916$ revog. As expressões entre colchetes não pertencem ao texto original.

169 BEVILAQUA, Clóvis. op. cit., p. 437. É também o posicionmento de TARDIVO, Carlo-Maria. op. cit., p. 82-91. 
Como bem esclarece Luigi Borsari, o texto do Codice Civile italiano, de 1865, revog. é muito claro ao se referir ao perecimento da coisa "per un caso fortuito" 170 pois, além de não poder realizar qualquer escolha em um evento de força maior, como em um bombardeamento, naufrágio ou terremoto, não é possível que em uma confusão ou desordem na qual o comodatário, devido a estas, só consegue salvar os objetos ao alcance de suas mãos, não deve ser responsabilizado pelo perecimento da coisa emprestada que estava fora de seu alcance. ${ }^{171}$

Da mesma forma o art. 1.882 do CC francês refere-se apenas a "la chose prêtée périt par cas fortuit", evento no qual é possível existir um momento tranqüilo para que a escolha seja realizada ${ }^{172}$.

E embora o art. 1.516, Parágrafo Único do CC português, de 1867, revog. se refira à destruição "ainda no caso de fôrça maior ou de acontecimento fortuito", este não foi isento das críticas de Luiz da Cunha Gonçalves ${ }^{173}$ por impor uma busca infrutífera ao comodatário da coisa emprestada em meio à força maior.

Assim, parece mais adequado, de lege ferenda, que a responsabilidade do comodatário só seja agravada pelo caso fortuito na hipótese do princípio do sacrifício da

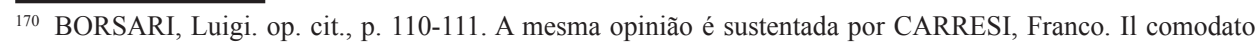
- Il mutuo. cit., p. 61-63 (= § 40), BRUNORI, Ernesto. op. cit., p. 24-25, FRAGALI, Michele. op. cit., p. 216-218 entre outros, sobre o art. 1805, $\S 1^{\circ}$ do CC italiano, idêntico ao art. $1865 \mathrm{CC}$ italiano de 1865 revog. Assim, DE CARVALHO SANTOS, João Manuel. op. cit., p. 421-423, afirma que a expressão "Se, correndo risco o objeto do comodato juntamente com outros do comodatário" do art. 1.253 CC/1916, que se repete no art. $583 \mathrm{CC} / 2002$, refere-se a um "acidente de firna rápida e pronta que não permite o salvamento de todos os objetos", sem especificar se tratar-se-ia de um caso fortuito ou de força maior. Neste sentido, o art. 1.882 CC Francês está em plena identidade com o art. 583 CC/2002, pois, ao utilizar o verbo "préférer" que equivale ao sentido do termo "antepuser", existente no art. 1.253 CC/1916 e no art. 583 CC/2002, vale dizer, a expressão "il [l'emprunteur] préfére la sienne" é sinônimo de "antepuser este [o comodatário] a salvação dos seus [objeto(s) do comodatário]". Também SAVATIER, René. Traité de la responsabilité civile en droit français - Les sources de la responsabilité civile. Paris: Générale de Droit et de Jurisprudence, 1939. v. 1, p. 227-238 (= ns. 182-189). O interessante, neste contexto, é perceber que a exclusão da responsabilidade do comodatário pela força maior - conseqüentemente se criticando a redação do art. 583 CC/2002 - somente é possível se for adotado o posicionamento daqueles que distinguem o caso fortuito da força maior, pois, caso contrário, seria uma contradição. Neste sentido, trata-se de assunto pacífico, a exclusão da responsabilidade do comodatário pela força maior.

171 CARRESI, Franco. Il comodato - Il mutuo. cit., p. 61-63 (= § 40). SANTOS, João Manuel de Carvalho. op. cit., p. 421-423, em complementação, sustenta que, sendo a concreta possibilidade de escolha um requisito indispensável para a caracterização do " princípio do sacrificio da coisa própria », não se aplica este dispositivo se o comodatário só tinha tempo de salvar as coisas que encontrou à mão, e entre estas não se encontrava a emprestada. Por exemplo, em um incêndio não se pode dizer que preferiu salvar o que lhe pertencia. Como também é impossível ao comodatário salvar a coisa emprestada quando se encontra em determinado lugar na época do acidente, ou quando se está em meio à um tumulto que não permite ter a faculdade de escolha, mas de apenas salvar os objetos que se encontram ao alcance de sua mão. Nestas circunstâncias ele se desobriga da obrigação de restituição como também não deve nenhuma indenização.

172 BAUDRY-LACANTINERIE, Gabriel; WAHL, Albert. op. cit., p. 364-366.

173 GONÇALVES, Luiz da Cunha. Tratado de direito civil. cit. p. 311. 
coisa própria, pois além de se tratar de uma empreitada impossível o salvamento da coisa emprestada, ofereceria ao comodatário um risco pessoal.

Embora alguns apenas se refiram ao risco de vida, ${ }^{174}$ mais adequado é entender como grave risco, ${ }^{175}$ descrito por Franco Carresi, ${ }^{176}$ como uma excludente da responsabilidade agravada do comodatário para salvar a coisa emprestada, seja pela travessia de um corredor em chamas ou pela subida por uma escada prestes a desabar.

Deve ser assim entendido como risco maior, ou seja, basta o risco ser menor para salvar a própria coisa que o comodatário se desobriga do salvamento da coisa emprestada. A inadequação da expressão "risco de vida", encontra-se na compreensão que a aferição dos níveis de risco deve ser feita frente a coisas de sua própria propriedade, frente à vida do comodatário e frente a terceiros que auxiliam no salvamento, e caracterizado o risco menor para salvar coisa própria poderá usar o seu tempo para salvá-la. ${ }^{177}$

Por outro lado, muito adequadamente o art. 583 do CC/2002 refere-se ao "dano ocorrido", vale dizer que ao perecimento, quer a deterioração. ${ }^{178}$

Cesare La Farina julga que o dano ocasionado na coisa emprestada pela aplicação do princípio do sacrifício da coisa própria seria apenas o perecimento, jamais a deterioração. ${ }^{179}$

Entretanto, não se justifica a aplicação do princípio do sacrifício da coisa própria, apenas para o caso fortuito que gere o perecimento, mas para qualquer efeito que venha a ter o caso fortuito, inclusive a deterioração. ${ }^{180}$

Existe também a discussão acerca destas duas vertentes do princípio do sacrifício da coisa própria e de sua existência no Direito Civil brasileiro.

A doutrina é unânime quanto à existência de duas vertentes, ${ }^{181}$ bem como de sua divergência quanto à configuração do risco, ${ }^{182}$ sendo que a primeira destas é descrita no início do art. $1.805, \S 1^{\circ}$ do CC italiano e do art. 1.803 do CC francês, e não no art. 583 do $\mathrm{CC} / 2002$ ou pelo art. $1.253 \mathrm{CC} / 1916$ revog.

\footnotetext{
174 Id. Ibid.

175 CARRESI, Franco. Il comodato - Il mutuo. cit., p. 62.

176 Id. Ibid.

177 CARRESI, Franco. Il comodato - Il mutuo. cit., 62.

178 Diferentemente, o art. 1.805, $\S 1^{\circ}$ do CC italiana refere-se à "se la cosa perisce", e o art. 1.882 do CC francês à "si la chose prêtée périt", ou seja, apenas ao perecimento, não à deterioração.

179 LA FARINA, Cesare. op. cit., p. 308-313. Segue a solução CARRESI, Franco. Il comodato - Il mutuo. cit., p. 61-62.

180 FRAGALI, Michele. op. cit., p. 214-216, sustenta que na hipótese de comodato de coisa avaliada refere-se tanto ao perecimento como a deterioração, salvo convenção expressa das partes sobre o assunto. Não há motivo de o mesmo raciocínio não ser aplicado ao princípio do sacrificio da coisa própria.

181 LA FARINA, Cesare. op. cit., p. 308-313, BRUNORI, Ernesto. op. cit., p. 24-25 e BAUDRYLACANTINERIE, Gabriel; WAHL, Albert. op. cit., p. 364-366.

182 BRUNORI, Ernesto. op. cit., p. 25.
} 
Nesta primeira face, somente a coisa emprestada está sobre o efeito do caso fortuito, enquanto a coisa pessoal do comodatário está em segurança. ${ }^{183}$

A abrangência desta vertente é tão vasta que parte da doutrina acaba por incluir a segunda dentro desta. ${ }^{184}$

$\mathrm{O}$ texto do art. $583 \mathrm{CC} / 2002$ apenas se refere a segunda vertente igualmente prevista, após a primeira pelos arts. $1.805, \S 1^{\circ}$ de CC italiano e $1.882 \mathrm{CC}$ francês, ${ }^{185}$ onde ambas as coisas estão em perigo de perecerem ou de se deteriorarem. ${ }^{186}$

Trata-se da previsão que, estando a coisa pertencente ao comodatário e a coisa emprestada em risco de perecer devido a um mesmo caso fortuito - como uma inundação - deve o comodatário, não podendo salvar as duas coisas, e devendo fazer uma escolha, decidir em prol da segunda. ${ }^{187}$

Por apresentar a particularidade que o risco deva recair sobre ambas as coisa - a emprestada e a pessoal do comodatário - esta vertente detém uma abrangência menor, e mais criteriosa.

Não se encontram elementos suficientes para afirmar que o art. 583 CC/2002 também se refira a primeira vertente, sendo apenas possível à configuração da responsabilidade agravada do comodatário pelo princípio do sacrifício da coisa própria na segunda vertente. ${ }^{188}$

Quanto ao seu fundamento, a própria existência do princípio do sacrifício da coisa própria demonstram um forte senso de (in)justiça na escolha a ser realizada pelo comodatário, bem como a presença ou-não de um reconhecimento do comodatário pelo comodante. ${ }^{189}$

O princípio do sacrifício da coisa própria pode ser entendido dentro do comodato como uma hipótese ao mesmo tempo excepcional e compreendida dentro do âmbito da responsabilidade objetiva.

183 LA FARINA, Cesare. op. cit., p. 308-313.

184 BAUDRY-LACANTINERIE, Gabriel; WAHL, Albert. op. cit., p. 364-366, e, inexatamente, BORSARI, Luigi. op. cit., p. 110-111, este último, apenas se referindo a capacidade de escolha.

185 Art. $1.805, \S 1^{\circ}$ do CC italiano: “...o se, potendo salvare uma delle due cose, ha preferito la propria”; Art. 1.882 do CC francês: “...ou si, ne pouvant conserver que l'une des deux, il préféré la sienne, il est tenu de la perte de l'autre".

186 BRUNORI, Ernesto. op. cit., p. 24-25

187 BAUDRY-LACANTINERIE, Gabriel; WAHL, Albert. op. cit., p. 364-366.

188 LA FARINA, Cesare. op. cit., p. 308-311, afirma, inadequadamente, que além destas duas faces, no princípio do sacrifício da coisa própria encontra-se embutida a hipótese de responsabilidade agravada do comodatário decorrente do « ocultamento » de objeto pessoal hábil ao mesmo uso que a coisa emprestada.

189 SANTOS, João Manuel de Carvalho. op. cit., p. 421-423. Nos termos deste último, a escolha do comodatário por suas coisas em detrimento das emprestadas, tratar-se-ia de uma "precedência injusta". 
Mesmo Franco Carresi ${ }^{190}$ que, em defesa do caráter concentrador da obrigação de custodiar e conservar a coisa com a diligência de um bom pai de família, caracteriza a hipótese como "excepcional" frente às demais do comodatário.

Da mesma forma, Francesca Carimini ${ }^{191}$ entende que ao princípio do sacrifício da coisa própria não se aplica o padrão da "culpa levis in abstracto", mas pode se presumir um nexo de causalidade entre a conduta do comodatário e o dano provocado.

Assim, também a regra esboçada por Jean Radouant ${ }^{192}$ detém uma omissão, uma vez que este somente trata da presença da culpa como agente antes ou depois do caso fortuito, uma vez que durante a responsabilidade seria afastada.

Entretanto, se durante a manifestação do caso fortuito este é legalmente imputado ao comodato, não resta alternativa do que caracterizar a responsabilidade agravada objetiva, embora que de forma excepcional dentro da estrutura do comodato.

Esta noção também foi conduzida por outros autores através da estruturação na hipótese de uma "praesumptio iuris et de iure", e não "praesumptio iuris tantum". 193

Não se trata de "praesumptio iuris tantum" pois não é facultado ao comodatário alegar que sem seu ato de preferência teriam as coisas emprestadas escapado do caso fortuito, ou executar uma prova para afastar sua responsabilidade, como ocorre no caso da "mora" e do "uso diverso". ${ }^{194}$

Assim, não se tem demonstrado necessária a presença da culpa para caracterizar a responsabilidade do comodatário pelo princípio do sacrifício da coisa própria. Bastaria o nexo causal e o dano, o que acaba por configurar uma hipótese que excepcionalmente vem a configurar a responsabilidade agravada objetiva do comodatário, respeitado seus requisitos e características intrínsecas.

\footnotetext{
${ }^{190}$ CARRESI, Franco. Il comodato - Il mutuo. cit., p. 62. A opinião de F. Carresi é acompanhada pela de P. Perlingieri, Codice civile annotato cit. (nota 119. 4. supra), p. 1364.

191 CARIMINI, Francesca. La responsabilità contrattuale del comodatario per perimento e deterioramento della cosa. Rassegna di diritto civile, Napoli, v. 1-2, 2003, p. 52, 71-72.

192 RADOUANT, Jean. op. cit., p. 181-183.

${ }^{193}$ MIRANDA, Francisco Cavalcanti Pontes de. Tratado de Direito Privado: direito das obrigações: obrigações e suas espécies - fontes e espécies de obrigações. cit., p. 77-102.

194 Id. Ibid. Conforme este último autor, a construção desta "praesumptio iuris et de iure" decorre da própria obrigação de resultado imposta ao comodatário como obrigação de fim - o que não ocorre, por exemplo, com o mandatário, que poderia afastar a sua responsabilidade nesta hipótese. Sobre este entendimento v. TAMBURRINO, Giuseppe. op. cit., p. 994-1006, LA FARINA, Cesare. op. cit., p. 308-313. Contrariamente a este entendimento CARRESI, Franco. Il comodato - Il mutuo. cit., p. 65, 67-69, 71-74 $(=\S 3,46,49$ 50 ), considera o contrato de comodato como detentor de um traço de anormalidade, pois a obrigação de restituição somente se configura após a extinção deste, não decorrendo de sua natureza.
} 


\section{Conclusão}

À luz de tudo que foi até aqui desenvolvido, a responsabilidade do comodatário adquire novo vigor. ${ }^{195}$

De um ponto de vista estático, através do princípio do sacrifício da coisa própria percebe-se, por um lado, que, embora inferior ao dos contratos onerosos e regenerado pela doutrina, o comodato detém um perfil econômico latente entre os contratantes, que incide de forma direta e imediata sobre toda a relação jurídica. ${ }^{196}$

Também neste sentido, o princípio do sacrifício da coisa própria vem sendo concebido, pela doutrina, como uma obrigação ao mesmo tempo excepcional, bem como eventual do comodatário, uma vez que se apresenta como exceção ao parâmetro da "culpa levis in abstracto valorizada", sem que com isso se deixe também de preencher requisitos erigidos pela doutrina e de respeitar os limites impostos para sua caracterização. ${ }^{197}$

Sobre esta visão concentrada na análise da relação existente entre as partes e do princípio do sacrifício da coisa própria em si, deve-se unir uma visão dinâmica que harmonize a fattispecie com o fundamento jurídico mais adequado para a sua sustentação.

Neste sentido, a responsabilidade do comodatário pelo princípio do sacrifício da coisa própria somente deve ser compreendida dentro da concepção de "responsabilidade agravada" do comodatário, isto é, das circunstâncias pelas quais o comodatário responde pelo caso fortuito, ${ }^{198}$ uma vez que a força maior sempre afasta sua responsabilidade.

Na realidade, as hipóteses pelas quais o comodatário é responsabilizado pelo caso fortuito podem decorrer ou de sua culpa, mas também de uma imposição objetiva do evento. ${ }^{199}$

Assim, o comodatário apresenta uma responsabilidade que poderia se denominar de multifacetada, pois dependendo da hipótese que se encontra responde ora subjetivamente, ora objetivamente.

Responde subjetivamente quando o comodatário encontra-se em mora, ou utiliza da coisa para um outro fim - uso - que não aquele previsto no contrato, ou que

\footnotetext{
195 Cf. CARIMINI, Francesca. op. cit., p. 52.

196 V. Id. Ibid., p. 65.

197 Cf. CARRESI, Franco. Comodato (diritto civile). cit., p. 692-696.

198 O princípio do sacrifício da coisa própria é, neste contexto, não somente uma exceção a regra, ou princípio, res perit domino, como também uma "exceção verdadeira" a este, em razão de seu substrato objetivo.

199 Trata-se justamente da regra esboçada por RADOUANT, Jean. op. cit., p. 182-183, 192-195, pela qual o comodatário responde pela caso fortuito se concorreu com sua culpa previamente a ocorrência deste evento. Esta regra, a contrario sensu, torna-se objetiva quando o evento é imposto ao comodatário durante sua manifestação.
} 
não decorra da natureza da própria coisa, uma vez que é clara a sua culpa na violação contratual realizada.

Por outro lado, responde objetivamente quando existe uma cláusula de assunção voluntária do caso fortuito ou da força maior, ou quando se trata do comodato de coisa avaliada, assumida, no Direito brasileiro, por pacto expresso, e, em outras legislações, como a italiana ou a francesa, como assunção tácita do "caso".

Quanto ao princípio do sacrifício da coisa própria tem-se questionado se tratar-se-ia de uma hipótese de responsabilidade agravada subjetiva, ou de responsabilidade agravada objetiva.

O que se percebe é que - pelos próprios elementos particulares desta hipótese, entre os quais a própria escolha durante um caso fortuito - não se pode entender, ou aplicar, a concepção de "violação contratual" com o sentido que esta expressão detém nos casos da mora e do uso diverso, pela não-valorização do comportamento culposo na fattispecie. $^{200}$

Tem-se demonstrado uma tendência repetitiva através dos tempos, de se identificar no princípio do sacrifício da coisa própria um substrato objetivo de responsabilidade, que seria corroborada pela própria discussão - mesmo que envolva os subjetivistas - acerca da configuração da hipótese quando existe uma diferença de valor entre os objetos. ${ }^{201}$

Tem-se, assim, configurado uma tendência, até regional, ${ }^{202}$ de prevalecer a presença do dano como elemento estruturante da responsabilidade, que tem também presumido o nexo de causalidade se presentes os requisitos do princípio do sacrifício da coisa própria, e se utilizando da caracterização de uma "praesumptio iuris et de iure".

\footnotetext{
${ }^{200}$ O elemento culpa mesmo em uma concepção de responsabilidade objetiva não deixa de, faticamente, existir. Entrementes, no âmbito desta, deixa de ser levado em consideração. Quando se tentou fundamentar o princípio do sacrifício da coisa própria em um critério subjetivo, o que se acabaria por configurar não era este em nenhuma de suas vertentes, mas sim o ocultamento. Esta confusão, que buscava a identidade entre estes dois institutos, só veio por reforçar a diferenciação destes, principalmente, para a caracterização do princípio do sacrificio da coisa própria como responsabilidade agravada objetiva.

201 A própria idéia de se embasar o princípio do sacrificio da coisa própria na eqüidade, funda-se em uma idéia fática-objetiva.

202 BUSNELLI, Francesco Donato. Principi per l'unificazione del diritto in materia di responsabilità extracontrattuale (Elementi constitutivi della fattispecie: colpa e ingiustizia). Roma e America. Diritto Romano Comune - Rivista di Diritto dell 'integrazione e unificazione del diritto in Europa e in America Latina, Roma, v. 3, 1997, p. 191-199. No mesmo sentido, GIMÉNEZ-CANDELA, Teresa. Una perspectiva historica de la responsabilidad objetiva. Roma e America. Diritto Romano Comune - Rivista di Diritto dell'integrazione e unificazione del diritto in Europa e in America Latina, Roma, v. 8, 1999, p. 117-129. e ALVES, José Carlos Moreira. A Responsabilidade Extracontratual e seu Fundamento: Culpa e Nexo de Causalidade. In Roma e America. Diritto Romano Comune - Rivista di Diritto dell'integrazione e unificazione del diritto in Europa e in America Latina, Roma, v. 10, 2000, p. 47-62.
} 
Através da concepção de uma presunção absoluta, frente a qual não cabe prova em contrário, ${ }^{203}$ conduz-se a uma idéia baseada no risco, como já ocorreu na L. Vis. 5 , 5, 2, e na exegese de Ulp. 28 ad ed., D. 13, 6, 5, 4, bem como dos dispositivos modernos referentes à fattispecie.

Portanto, o princípio do sacrificio da coisa própria deve ser entendido, tendo-se por fundamento tanto uma reconstrução histórica, bem como as tendências sempre renovadoras do Direito, como hipótese de responsabilidade do comodatário ao mesmo tempo excepcional e objetiva. No fundo, o que parece acontecer, é que boa parte dos escritores dos séculos XIX e XX apresentam um medo, ou receio, despropositado, de fundamentar a fattispecie na responsabilidade objetiva, e, assim, ciram figuras de responsabilidade ??? e desnecessária ao progresso da Ciência do Direito

São Paulo, agosto de 2008

\section{Referências}

ALTAVILlA, Enrico. Forza maggiore e caso fortuito. Nuovo Digesto Italiano, Torino, v. 16, p. 113-120, 1938.

ALVES, José Carlos Moreira. A Responsabilidade Extracontratual e seu Fundamento: Culpa e Nexo de Causalidade. Roma e America. Diritto Romano Comune - Rivista di Diritto dell'integrazione e unificazione del diritto in Europa e in America Latina, Roma, v. 10, p. 47-62, 2000.

ALVIM, Agostinho. Da inexecução das obrigações e suas conseqüencias. 5. ed. São Paulo: Saraiva, 1980. p. 1-374 (= n. 1-298).

BARBIERI, Ezio Maria; NAPOLETANO; Vicenzo; NOVITÀ, Mario. I contratti reali: mutuo deposito - comodato - pegno - contratto estimatori. 2. ed. Torino: UTET, 1979.

BAUDRY-LACANTINERIE, Gabriel; WAHL, Albert. Traité théorique et pratique de droit civil: de la société, du prêt, du depôt. 2. ed. Paris: Des lois et des arrêts, 1900. p. 1-660 (= n. 1-1318).

BEVILAQUA, Clóvis. Código civil dos Estados Unidos do Brasil. São Paulo: Francisco Alves, 1917. v. 4, p. 5-450.

BORSARI, Luigi. Commentario del Codice Civile Italiano. Torino: UTET, 1881. v. 4, t. 2, p. 5936. $(=\S 3914-4454)$.

\footnotetext{
${ }^{203}$ Expressamente, esta prova cabe para as hipóteses de mora e de uso diverso, que configuram hipóteses de responsabilidade agravada subjetiva. Esta conclusão, por ser expressa, não pode ser transportada para o principio do sacrificio da coisa própria.
} 
BRUNORI, Ernesto. Dei contratti specialli - Comodato. In: FINZE, Enrico; D’AMELIO, Mariano (Orgs.). Commentario al Codice Civile. Firenze: Barbèra, 1949, v. 2, p. 1-507.

BUSNELLI, Francesco Donato. Principi per l'unificazione del diritto in materia di responsabilità extracontrattuale (Elementi constitutivi della fattispecie: colpa e ingiustizia). Roma e America. Diritto Romano Comune - Rivista di Diritto dell'integrazione e unificazione del diritto in Europa e in America Latina, Roma, v. 3, p. 191-199, 1997.

BUSSI, Emilio. La formazione dei dogmi di diritto privato nel diritto comune - Contratti, successioni, diritti di famiglia. In: Studi di diritto privato italiano e straniero diretti da Mario Rotondi. Padova: CEDAM, 1971. v. 27, p. 3-366 (=n. 1-77).

CARIMINI, Francesca. La responsabilità contrattuale del comodatario per perimento e deterioramento della cosa. Rassegna di Diritto Civile, Napoli, v. 1-2, p. 50-74, 2003.

CARRESI, Franco. Comodato (diritto civile). Novissimo Digesto Italiano, Torino, v. 3, p. 692-696, 1959.

. Il comodato - Il mutuo. In: VASSALLI, Filippo (Org.). Trattato di Diritto Civile Italiano. Torino: UTET, 1950. v. 8, t. 2, p. 5-136.

CHIRONI, Giampietro. La colpa nel diritto civile odierno: colpa contrattuale. Torino: Fratelli Bocca, 1884. p. III-371 (=n. I-340).

DE RUGGIERO, Roberto; MAROI, Fulvio. Istituzione di diritto privato: diritto di obbligazione e contratti - tutela dei diritti. 6. ed. Messina: Giuseppe Principato, 1947. v. 2, p. 1-732 (= § 1-152).

DIAS, José de Aguiar. Comodato. Repertório Enciclopédico do Direito Brasileiro, Rio de Janeiro, v. 10, p. 24-26, 1947.

ENNECCCERUS, Ludwig; KIPP, Theodor; WOLFF, Martin. Lehrbuch des Bürgerlichen Rechts: Recht der Schuldverhältnisse. 28. ed. Marburg: G. Braun, 1928. v. 1, t. 2, p. 1-734 (= § 225-470).

ENNECCERUS, Ludwig; KIPP, Theodor; LEHMANN, Heinrich; WOLFF, Martin. Lehrbuch des Bürgerlichen Rechts: Recht der Schulverhältnisse. Tübingen: Mohr, 1954. v. 2, p. 569-1051.

FERRARIO, G. A. Comodato. Enciclopedia Giuridica Italiana, Milano, v. 3, 1930. p. 385-405.

FONSECA, Arnoldo Medeiros da. Caso fortuito e Teoria da Imprevisão. 2. ed. Rio de Janeiro: Imprensa Nacional, 1943. p. 9-336.

FORCHIELLI, Paolo. I contratti reali. Milano: Giuffrè, 1952. p. 1-177.

FRAGALI, Michele. Del comodato. In: SCIALOJA, Antonio; BRANCA, Giuseppe (Orgs.). Commentario del codice civile: delle obligazioni. Bologna: Nicola Zanichelli, 1953. v. 4, t. 1, p. I-571.

FRANÇA, Rubens Limongi. Contrato de empréstimo. Enciclopédia Saraiva do Direito, São Paulo, v. 19, 1977. p. 320-324. 
GIANTURCO, Emanuele. Contratti Speciali: donazioni - enfiteusi - superficie - mutuo - comodato - deposito - sequestro. Napoli: Luigi Pierro, 1904. p. 7-303.

GIMÉNEZ-CANDELA, Teresa. Una perspectiva historica de la responsabilidad objetiva. Roma e America. Diritto Romano Comune - Rivista di Diritto dell'integrazione e unificazione del diritto in Europa e in America Latina, Roma, v. 8, 1999, p. 117-129.

GONÇALVES, Luiz da Cunha. Princípios de direito civil luso-brasileiro: direito das obrigações. São Paulo: Max Limonad, 1951. v. 2, p. 519-1075 (=§ 187-468).

. Tratado de direito civil: em comentário ao código civil português. 2 ed. São Paulo: Max Limonad, 1956. v. 8, t. 1, p. 11-468 (= § 1101-1177).

KOBER, Karl; STAUDINGER, Julius Ritter. Leihe. In Kommentar zum Bürgerlichen Gesetzbuch und dem Einführungsgesetz - Recht der Schuldverhältnisse. München: Schweitzer, 1929. v. 2, t. 2, p. 636-650 (= $§ 598-606)$.

LA FARINA, Cesare. Comodato. Enciclopedia Forense, Milano, v. 2, 1958. p. 308-313.

LAURENT, François. Principes de Droit Civil Français. 3. ed. Bruxelles: B.C., 1878. t. 26, p. 5-554 (=n. 1-530).

LUZZATTO, Giuseppe Ignazio. Caso fortuito e forza maggiore come limite alla responsabilità contrattuale: la responsabilità per custodia. Milano: Giuffrè, 1938. v. 1, p. 1-265.

. Custodia (diritto romano). Novissimo Digesto Italiano, Torino, v. 5, 1960. p. 92-94.

MESSINEO, Francisco. Manuale di diritto civile e comerciale: codici e norme complementare singoli rapporti obbligatori - diritti delle successioni per causa di morte - elementi di diritto privato internazionale. 7. ed. Milano: Giuffrè, 1957. v. 3, p. 3-594 (= n. 139-169).

MIRABELLI, Giuseppe. Il comodato - Il mutuo - La constituzione di rendita - Il deposito e il sequestro - Il pegno - Il contratto vitalizio - L'anticresi - La fideiussione - Il giuoco e la scommessa - La transazione. In: FIORI, Pasquale; BRUGI, Biagio (Orgs.). Il diritto civile italiano: dei contratti speciali. Torino: UTET, 1924. v. 12, p. 3-748.

MIRANDA, Francisco Cavalcanti Pontes de. Tratado de direito privado: direito das obrigações: obrigações e suas espécies - fontes e espécies de obrigações. 2. ed. Rio de Janeiro: Borsoi, 1958. t. 22, p. 7-403 (= § 2679-2766).

Tratado de direito privado: parte especial. 2. ed. Rio de Janeiro: Borsoi, 1958. t. 23, p. 5$430(=\S 2767-2880)$.

Tratado de direito privado: parte especial. 2. ed. Rio de Janeiro: Borsoi, 1964. v. 46, p. 3$412(=\S 4957-5037)$.

PASTORI, Franco. Comodato (diritto romano). Novissimo Digesto Italiano, Torino, v. 3, 1959. p. 688-692. 
PERLINGIERI, Pietro. Codice civile annotato con la dottrina e la giurisprudenza: delle obbligazioni. Napoli: Scientifiche Italiane, 1991. v. 4, t. 2, p. 761-1950.

PERRIS, Corrado. Comodato (contratto di). Nuovo Digesto Italiano, Torino, v. 16, 1938. p. 403408.

PLANIOL, Marcel [et al.]. Traité pratique de droit civil français: contrats civils. Paris: Générale de Droit, 1932. t. 11, p.1-966 (=§ 763-1605).

POTHIER, Robert-Joseph. Traités du prêt a usage et du precaire. In: Euvre de Pothier. 3. ed. Paris: Marchal et Billard, 1890. v. 5, p. 1-38 (=n. 1-97).

RADOUANT, Jean. Du cas fortuit et de la force majeure. Paris: Rousseau, 1920. p. 3-337.

RODRIGUES, Silvio. Contrato de comodato. Enciclopédia Saraiva do Direito, São Paulo, v. 19, 1977. p. 237-241.

SANTARELLI, Umberto. Comodato nel diritto medievale e moderno. Digesto delle Discipline Privatistiche: sezione civile, Torino, v. 3, p. 34-37, 1998.

SANTOS, João Manuel de Carvalho. Código Civil Brasileiro Interpretado. 8. ed. Rio de Janeiro: Freitas Bastos, 1964. v. 17, p. 5-471.

SAVATIER, René. Traité de la responsabilité civile en droit français: les sources de la responsabilité civile. Paris: Générale de Droit et de Jurisprudence, 1939. v. 1, p. 1-609 (=n. 1-454).

SERTORIO, Luigi. La "culpa in concreto,, nel diritto romano e nel diritto odierno. Torino: Fratelli Bocca, 1914. p. 1-291.

TAMBURRINO, Giuseppe. Comodato (diritto civile). Enciclopedia del Diritto, Milano, v. 7, 1960. p. 994-1.006.

TARDIVO, Carlo-Maria. Studi sul commodatum. Archivio Giuridico "Filippo Serafini", Modena, v. 204, p. 5-91, 1983.

TROPLONG, Raymond-Théodore. Le droit civil expliqué: du prêt. Paris: Charles Hingraus, 1845. t. 14 , p. I-447 (= préface, n. 1-500). 